\title{
THE OPPORTUNITY COST OF CAPITAL OF US BUYOUTS
}

\author{
Alexander Peter Groh \\ Oliver Gottschalg
}


The CIIF, International Center for Financial Research, is an interdisciplinary center with an international outlook and a focus on teaching and research in finance. It was created at the beginning of 1992 to channel the financial research interests of a multidisciplinary group of professors at IESE Business School and has established itself as a nucleus of study within the School's activities.

Ten years on, our chief objectives remain the same:

- Find answers to the questions that confront the owners and managers of finance companies and the financial directors of all kinds of companies in the performance of their duties

- Develop new tools for financial management

- Study in depth the changes that occur in the market and their effects on the financial dimension of business activity

All of these activities are programmed and carried out with the support of our sponsoring companies. Apart from providing vital financial assistance, our sponsors also help to define the Center's research projects, ensuring their practical relevance.

The companies in question, to which we reiterate our thanks, are:

Aena, A.T. Kearney, Caja Madrid, Fundación Ramón Areces, Grupo Endesa, Royal Bank of Scotland and Unión Fenosa.

http://www.iese.edu/ciif/ 


\title{
THE OPPORTUNITY COST OF CAPITAL OF US BUYOUTS
}

\author{
Alexander Peter Groh ${ }^{1}$ \\ Oliver Gottschalg ${ }^{2}$
}

\section{Abstract}

This paper addresses the problem to accurately determine buyout opportunity cost of capital for performance analyses. It draws on a unique and proprietary set of data on 133 United States buyouts between 1984 and 2004. For each of them, we determine a public market equivalent that matches it with respect to its timing and its systematic risk. We show that under realistic mimicking conditions, the average opportunity cost of capital is below the commonly used benchmark S\&P 500. The surprising result has a simple explanation: ex post, many of the transactions mimicking the buyouts would have defaulted in the public market. Only under relaxed assumptions is the average opportunity cost of capital close to the average index return. Our sensitivity analyses highlight the necessity of a comprehensive risk-adjustment that considers both operating risk and leverage risk for an accurate assessment of buyout performance. This finding is particularly important as existing literature on that topic tends to rely on benchmarks without a proper risk-adjustment.

JEL Classification: G11, G24, G32

Keywords: Private Equity, Risk-Adjusted Performance, Buyout, Benchmarking Alternative Assets.

\footnotetext{
${ }^{1}$ Visiting Professor, Finance, IESE and GSCM - Montpellier Business School

${ }^{2}$ Professor, HEC School of Management
} 


\section{THE OPPORTUNITY COST OF CAPITAL OF US BUYOUTS}

\section{Introduction}

Since the late 1970s buyouts ${ }^{1}$ have become an important asset class with significant economic impact. ${ }^{2}$ Yet relatively little is known about the risk and return characteristics of this type of investment. This is largely due to two factors. First, buyout investments differ substantially from public market investments in several important characteristics, especially regarding liquidity and information symmetry. This implies theoretical challenges with respect to the assessment of their risk and return. Second, buyout investments are a sub-category of the private equity asset class for which general disclosure requirements do not exist. In the absence of detailed information on the underlying transactions and their investment characteristics, risk-adjusted returns are impossible to calculate. To prove that is the major contribution of our paper, we assess the opportunity cost of capital of buyout transactions by public market investments with an equal risk profile. For this assessment, we draw on a unique and proprietary set of data on target-company and industry characteristics, as well as the applied financial structures of 133 United States buyouts. Based on this information, we construct a mimicking portfolio of investments in the S\&P 500 Index, with additionally borrowed or lent funds to adjust for the applied degrees of leverage. These mimicking investments match the buyouts in terms of the timing of their cash flows and their systematic risk pattern. The systematic risk of buyout transactions usually changes during the holding period. Being initially high due to the amount of debt used for financing the transaction, the risk decreases in the following periods as debt is repaid. Our mimicking investments exactly replicate this evolution of the buyout risk patterns over time.

The chosen public market equivalent is not intended to present a "buyout pricing model" nor does it imply that buyouts can be replicated adequately with traded securities. We simply propose an approach to benchmarking them in what we regard as the best possible way. For

\footnotetext{
1 In the literature, buyout transactions are variously labelled (e.g., leveraged buyout, management buyout, institutional buyout, management buy-in, etc.) and these terms are often used synonymously. In this paper the term "buyout" is preferred as being the broadest covering the different facets of this transaction type.

2 The historical evolvement of the asset class, different cycles and its economic impact are well reported in Lowenstein (1985), Sahlman and Stevenson (1985), Sahlman (1990), Smith (1990), and Kaplan and Stein (1993) for the late 1970s and 1980s. See Jeng and Wells (1998) for the 1980s and 1990s. See Gompers and Lerner (1999a) and (2000) for an overall summary, and see the current yearbooks of the National Venture Capital Association and the European Private Equity and Venture Capital Association for actual market data.
} 
this method, we adopt the perspective of a well-diversified investor, such as a fund of fund investor, pension fund or a university endowment. This is a reasonable assumption as such investors are the primary providers of capital for buyout transactions. Consequently, we do not consider idiosyncratic risks in our analyses because these investors are not affected by idiosyncratic shocks. Our stylized model follows the alternative decision to either invest in buyouts or in quoted assets. Thereby we control for the systematic risk involved, but not for liquidity risk, size, or other factors.

The contributions of this paper are several. First, our method of benchmarking the buyout asset class with the public market could evolve into a standard for buyout performance measurement. Second, we apply this method in an empirical analysis on a comprehensive and unique data set and reveal the importance of a correct specification of risks taken by lenders, cost of borrowing and lending, and potential changes of the operating risk profile of the buyout targets. We illustrate that it is insufficient to assess the performance of buyout transactions without thoroughly determining leverage ratios, risks borne by lenders, and controlling for the systematic risks carried by the sponsors. This finding is important for the interpretation of results from some of the most recent literature, such as Phalippou and Gottschalg (2008), Kaplan and Schoar (2005) and Ljungqvist and Richardson (2003), as data limitations depending on their data sources make our proposed way of risk separation impossible in these studies. We show that, under what we regard as the most realistic mimicking approach, the average buyout opportunity cost of capital is $9.07 \%$, while the median is $12.16 \%$. This is significantly $3.29 \%$ $(2.79 \%)$ below what would have been earned on average (medial) if the investors had invested in the time matching S\&P 500 portfolio (with an average return of 12.36\%, and a median of $14.95 \%)$. It seems surprising that the average return of the levered index portfolio is less than the average return of the index. However, the explanation is rather simple: Many public market mimicking transactions would have defaulted due to the leverage ratios applied in the buyouts. Default is triggered if the equity value invested in the mimicking portfolio melts down to zero.

The detected deviation from the S\&P 500 returns results from controlling for the risks taken by lenders in the buyout transactions and the corresponding cost of debt. Relaxing our approach, and assuming riskless borrowing and lending, leads to average (median) opportunity cost of capital of $12.89 \%(12.59 \%)$. The average return is slightly higher than the average return earned if the correct mimicking portfolio is indeed the S\&P 500. However, the median return is slightly smaller. As a conclusion, we claim that neglecting different degrees of leverage, and using the returns of the S\&P 500 for simplicity as opportunity cost of capital to benchmark buyout transactions leads to preliminary results, unless the detected difference is an appropriate premium for illiquidity and/or other risk factors. However, the exposure of buyout transactions to other risk factors is not yet sufficiently researched, and this is also not the subject of this paper.

The third contribution of our paper are the sensitivity analyses and robustness checks, where we provide further insights into the nature of buyout transactions and the financial drivers of their performance. The analyses confirm that buyout transactions tend to be more successful relative to their public market benchmark if the buyout fund managers are able to transfer substantial parts of the risk to the lenders.

Finally, it is important to note that our approach relies on completed and audited transactions only. This removes the necessity of dealing with interim valuations and missing values, as reported by Rotch (1968), Poindexter (1975), Peng (2001a and 2001b), Quigley and Woodward (2002 and 2003), Cochrane (2005), and Phalippou and Gottschalg (2008). It is due to issues such as these that performance analyses become both difficult and questionable because the methods 
of correction transfer the historical development and return patterns on the non-exited and current transactions. This might cause a substantial bias due to market conditions that have changed meanwhile.

\section{Background}

Buyouts, as Sahlman (1990), and Lerner (2000) point out, represent one strand of the private equity (PE) asset class. This asset category is based on the relationship between an institutional investor and an intermediary (the PE fund or investee). PE funds are usually structured as a limited partnership, with a management team (termed the "general partner") that manages the investments of the limited partners. Investors in the fund then hold shares as limited partners. Buyout funds concentrate their investments on mature companies. In most cases, the companies' shares are not traded on a public stock market, though a particular type of transaction described by Lowenstein (1985), called "going privates," target quoted companies. A defining feature of the asset class is that, for the "going privates" as well as for the privately held target corporations, once a general partner has invested in a company, its shares are no longer publicly traded over her holding period. The exposure is typically structured as, or highly like, equity claims (common and preferred). For each transaction an investment vehicle is created, funded by one or several buyout funds as well as other parties, such as senior and subordinated debt providers and mezzanine investors. The nature of these is investigated by Kaplan and Stein (1990) and Cotter and Peck (2001). The target company's management team, its employees or new external managers may also subscribe for equity stakes, but their stakes are usually small compared to the institutional investors' participation. The transaction vehicle acquires assets or shares of the target company and/or will merge with it, thus creating a unique opportunity highlighted by Jensen (1986) to specify a capital structure and design particular claims and incentives. The principle to found a special purpose vehicle for every single transaction is a particularly important feature with respect to the subsequently proposed mimicking approach. The legal construction secures that the liability of the buyout fund is limited to its equity exposure. The sponsor's individual assets do not serve as collateral for other ones. As a consequence, debt financing for an individual portfolio company is granted against the particular portfolio company's assets only, and hence, more costly than the risk free rate.

The transaction date is called the closing date. At the end of the holding period (called exit), all claims are usually sold either via privately negotiated sales or through Initial Public Offerings. If not all shares are sold at IPO, the general partners liquidate their holdings subsequently or directly transfer the shares to the limited partners. In any case it is not the investors' goal to maintain exposure in the public stock market. Unsuccessful engagements are written off, eventually to a zero value. Some transactions might be only partly sold and/or re-levered to benefit once more from debt finance.

Buyout funds tend to act as active investors, as comprehensively discussed by Jensen (1989a and 1989b). Their role involves monitoring, managing and restructuring the target companies to create value. Kaplan (1989a and 1989b, 1991), Lichtenberg and Siegel (1990), Smith (1990), and Berg and Gottschalg (2005) argue that this is a key determinant for the success of buyout transactions. To secure their influence on the target companies, buyout funds seek to obtain the majority of voting rights either alone or together with other financial investors via equity 
syndications. This is not a necessary condition however, and, depending on the buyout size and structure, the majorities can vary.

A second strand of the PE asset class is constituted by VC investments, as discussed by Bygrave and Timmons (1992), Gompers (1998) and Gompers and Lerner (1999a and 2000). Buyouts and venture capital differ substantially in terms of the investment risk profile. While buyout funds invest in mature companies in traditionally stable industries using financial leverage, VC funds typically acquire minority stakes of early stage businesses in volatile growth industries with minimal or no debt financing. These fundamental differences make it necessary to treat the two sub-categories of the private equity asset class separately in the assessment of risk and return; it is also why this paper focuses exclusively on buyout transactions.

\section{Related Literature}

Strikingly, recent research on the risk and return of private equity has lead to contradictory findings. As we will show in this section, different approaches to correct for sample selection biases and to adjust for risk may be responsible for a large part of these inconsistencies. Furthermore, it is important to note that many studies do not sufficiently differentiate between the different risk-characteristics of the venture capital and the buyout asset class. The key papers are discussed below before we highlight how our paper differs from the related literature.

Gompers and Lerner (1997) address the "stale price" problem and propose market tracking as a tool for measuring risk-adjusted returns of buyouts. The term "stale price" is used to describe the fact that market valuations of PE transactions are only available at two dates (if at all): the entry and the exit date. Hence, the common risk measure standard deviation of periodic returns is meaningless for the asset class. The authors benchmark the individual transactions by building equally weighted indexes of publicly quoted companies sharing the same three-digit SIC codes. They then analyze one single buyout fund using these indexes as a performance indicator (if neither cash payments nor write-offs exist), modeling the quarterly exposure of its investments. If a payment or write-off occurs, then a new company value can be calculated and attributed to the transaction. Gompers and Lerner (1997) concede that their approach assumes perfect correlation between the target company valuations and the chosen index. Moreover, the authors argue that this could overstate the risk involved. Using their approach, the authors find superior performance for this single buyout fund.

Ljungqvist and Richardson (2003) use extensive data obtained from a fund of fund investor regarding cash outflows, inflows and management fees for investments in 73 different PE funds. To determine risk-adjusted returns they calculate industry beta factors using the methodology of Fama and French (1997). Without data on the leverage of the target companies, they are unable to correct for different degrees of leverage, and therefore implicitly assume average industry debt/equity ratios within their analysis. From this, they obtain an average beta factor of all the different PE fund portfolios of 1.08 and an average annual internal rate of return of $21.83 \%$. This greatly exceeds the S\&P 500 Index performance during the same period of $14.1 \%$ per annum. The authors argue that, provided the degrees of leverage were no higher than about twice the industry average, a risk-adjusted premium exists for the PE transactions. However, they acknowledge that their PE-fund sample may not be a random draw from the general population.

Jones and Rhodes-Kropf (2003) investigate the idiosyncratic risks of PE transactions, arguing that they play an important role that must be priced. They find that investors in PE funds do

4 - IESE Business School-University of Navarra 
not earn positive alphas. Surprisingly, they also find that funds exposed to more idiosyncratic risk earn higher returns than more diversified portfolios. Groh, Baule and Gottschalg (2009) determine idiosyncratic buyout risks with a contingent claim approach based on the Ho and Singer (1984) model to price risky debt with an amortization payment. They find high Sharperatios of the buyouts but face a severe selection bias in their sample of transactions.

Quigley and Woodward (2002) and Woodward and Hall (2003) develop a VC price index based on the Repeat Sales Regression Method introduced by Bailey, Muth and Nourse (1963) to benchmark real estate investments. Quigley and Woodward (2002) further correct for sample selection bias with Heckit Two Step Regression. The authors use proprietary data on 5,607 companies that received venture capital in 12,553 financing rounds between 1987 and 2000. Quigley and Woodward (2002) calculate Sharpe-ratios of their VC index and of the S\&P 500, and the NASDAQ Index. Both stock market indexes have to be considered superior to VC in terms of the ratio between risk and return. However, the authors conclude that for diversification purposes, securities portfolios should include 10\% to 15\% of VC exposure.

Similar to Peng (2001a and 2001b) and Quigley and Woodward (2002), Cochrane (2005) points out that empirical VC research usually only observes valuations if target companies go public, receive new financing or are acquired by third parties. These events are more likely to occur when good returns have already been experienced and this results in a sample selection bias that the author overcomes via a maximum likelihood estimate. He measures the probability of observing a return as the company values increase. His approach implies the assumption that historical development patterns of the portfolio companies remain stable and are applicable to estimate the value of current and non-exited projects. Cochrane (2005) uses data on 16,613 financing rounds between 1987 and June 2000 for 7,765 target companies from the VentureOne database. This database includes buyout and venture capital transactions but the VC segment notably dominates the data. With his reweighing procedure Cochrane (2005) calculates an arithmetic mean return of 59\% and underlines the high idiosyncratic risks of the particular transactions. He directly models the returns to equity and does not control for leverage risks. He compares the returns with the corresponding returns of the S\&P 500 Index and with several portfolios taken from the NASDAQ Index. Considering these different benchmark portfolios he finds alphas ranging from 22\% to 45\%. Regarding the slopes of the regressions he argues that VC is riskier than the S\&P 500 Index. For the different NASDAQ portfolios Cochrane (2005) determines regression slopes between 0.5 and 1.4 and argues that VC can have either greater or lower risk than the benchmark depending on the choice of the NASDAQ portfolio.

Kaplan and Schoar (2005) employ a public market equivalent approach to benchmark PE funds. They construct a mimicking portfolio for a large sample of PE funds contained in the Thomson Venture Economics database, investing the same amount over an equally long period in the S\&P 500 Index and comparing the PE fund performance to the index returns. Within their approach, Kaplan and Schoar (2005) presume that PE investments are as risky as the S\&P 500 portfolio and hence, have a beta equal to one. The authors conclude that average buyout fund returns are, after fees, slightly smaller than those of the S\&P 500. Gross of fees the asset class earns returns exceeding the chosen benchmark. They also report a strong persistence of the performance (negative as well as positive) of the particular funds and a higher performance for larger funds and more experienced management teams. Kaplan and Schoar (2005) acknowledge that their results may be misleading however, as by not controlling for different risk patterns in the individual transactions they assume that the appropriate buyout cost of capital is the return 
of the S\&P 500 Index. They also do not correct for a potential selection bias that might exist in their sample.

Phalippou and Gottschalg (2008) extend the Kaplan and Schoar (2005) article. They calculate public market equivalents for cash flows to and from buyout funds, and also use the time matching returns of the S\&P 500 as opportunity cost of capital. They focus on the correction of unrealized, but reported net asset values and run several analyses applying various approaches to partially or fully write them off. They find that gross of fees their sample funds outperform the S\&P 500 by 3\% p.a. Net of fees the performance is 3\% below the benchmark. In a robustness check, they calculate unlevered and levered beta factors with a method similar to the one we will apply to perform a risk-adjustment. However, without data on the target companies' leverage, the authors are unable to correct for different degrees of leverage in their sample transactions. They calculate equity beta factors similar to Ljungqvist and Richardson (2003) with initial debt/equity ratios of 3 and final debt/equity ratios at average industry levels. In their unlevering and re-levering approach they assume a corporate tax rate of 35\%, a debt beta of 0.25 for the buyouts and 0 for the public market and do not differentiate the risks of debt tax shields in the quoted and unquoted market segment. They also do not control for different cost of borrowing and lending. Using the average buyout case, Phalippou and Gottschalg (2008) find underperformance of the buyouts with respect to the S\&P 500.

Our study differs from and aims to extend prior work in several ways. First and most importantly, it constitutes the first large-scale analysis on the cost of capital for buyouts that fully corrects for operating risk, leverage risk, and leverage cost. Using precise information on the valuations of individual target companies, their competitors in their industry sector and on the capital structures of the investment vehicles at the closing date and at exit, it becomes possible for us to attribute a systematic risk measure to every transaction. This risk measure is neither an average over several transactions nor constant over time. There is, rather, an individual risk pattern for every single transaction. This pattern typically starts at higher risks due to initially higher degrees of leverage, and consecutively decreases, due to the redemption of debt. The redemption capabilities of the target corporations vary to a great extent and, hence, this underlines the variety of the risk patterns in buyout financing. We are able to control for these patterns by constructing well-defined, equally risky mimicking investments that can be used to determine the opportunity cost of capital of buyout transactions. We show that the consideration of leverage risk and cost is of great importance. Also, as Ljungqvist and Richardson (2003), and Kaplan and Schoar (2005) note, any findings regarding the performance of buyouts that do not appropriately adjust for the effect of leverage have to be interpreted with great caution. We are able to illustrate the effect of different choices regarding the treatment of the risk patterns and the cost of debt for the relative performance of this asset class.

Further, this paper focuses exclusively on investments of buyout funds, as the category of PE in which leverage plays a crucial role. It thereby avoids mixing two asset classes (venture capital and buyouts) that have substantially different risk and return characteristics. Additionally, we only rely on fully completed (exited and audited) transactions. Hence, we avoid the problem of missing values and do not need to vaguely estimate interim valuations for our transactions from historical return patterns nor to handle reported net asset values. Next, we provide detailed insights into risk characteristics and drivers of performance of this asset class. Our findings contrast the performance impact of: a) systematic operating risk, and, b) leverage risk; with c) the joint impact of both factors. Moreover, we explicitly analyze the sensitivity of our results with respect to different assumptions regarding the risk patterns of the individual 
transactions. Therefore we vary the assumptions about debt risk, the risk of debt tax shields, credit spreads, and operating risks in the industry sectors.

\section{Data Collection and Sample Description}

The availability of data of sufficient breadth and depth has been one of the key constraints in addressing the question of the opportunity cost of capital for buyouts. As we show in this paper, mimicking buyout investments with public market instruments on a risk-adjusted basis requires information on the industry segment of the target companies, the timing and size of underlying cash flows, as well as the capital structure of the acquiring investment vehicles at least at entry and exit. This data is neither publicly available, nor is it listed in any of the commonly used databases, such as Thomson Venture Economics or Venture0ne. Rather, it can only be gathered directly from institutions investing in buyouts as either general or limited partners. While this approach has advantages regarding the depth of available data, it leads to potential selection and survivorship biases. In the following, we describe the data sources and sample characteristics of the data used in this study and discuss a potential bias.

Our dataset is compiled from information on buyout funds made available to us anonymously either directly from general partners or through limited partners. Limited partners collect detailed information on general partners as part of the due diligence processes for their fund allocations. Each year, limited partners often screen hundreds of new buyout funds. In a special document (the so-called Private Placement Memorandum - PPM), general partners describe their previous transactions in order to raise a new fund. The PPM are submitted to potential limited partners and used by them to assess the general partner's quality and strategy. These documents contain information about all past transactions carried out by the general partner. The data on individual transactions used in this study has been extracted from PPM. Our data providers are among the world's largest limited partners and collectively manage more than United States $\$ 40$ billion in the PE asset class. Needless to say, PPM documents are highly confidential and, to the best of our knowledge, have never been used in academic research.

As no standard format exists for reporting transactions in PPM, the documents are very heterogeneous in terms of the level of detail provided for each transaction - both within one fund and across general partners. As a result, the data necessary to perform our proposed method of risk-adjustment was extracted only for a small subset of transactions. Moreover, as only fully exited transactions are considered here, the size of the available sample shrinks further. Because this study's objective is to assess the opportunity cost of capital for "buyouts," we only consider investments performed by funds that refer to themselves explicitly as a "buyout fund." For instance, the 122 PPM supplied to us by our research partners described 2,264 realized buyout transactions (1,001 of which were in the United States) made through 170 buyout funds (some PPM report on several funds) raised between 1981 and 2004. From this large number of transactions, we only collect 152 transactions for which the following data is available. First, for closing: the date, company valuation, acquired equity stake, amount paid for the equity, target-company industry and a short product and market description, or description of competitors (in order to determine its SIC code). Second, for the exit: the date, company valuation, equity stake and amount returned to the buyout fund. Finally, in order to verify that the underlying cash flows are correctly matched, the investment's gross internal rate of return reported in the PPM is needed. Some problems and shortcomings of the internal rate of return as a performance measure for buyout transactions are discussed in Kaplan and Schoar 
(2005), Phalippou (2008), and Phalippou and Gottschalg (2008). However, we only use the internal rates of return of the transactions to verify that we correctly match all their underlying cash flows.

The vast majority of the collected 152 target companies are based in the United States, with the remainder based in the United Kingdom, continental Europe and Japan. As the non-United States results would lack statistical weight for any individual country while also distorting the United States results and raising questions about cross-currency returns, the availability of public peers and adequate benchmark portfolios, we decided to exclude all non-United States transactions. This finally leaves us with 133 transactions executed by 41 different funds. For each of these transactions we are able to create the exact individual financial risk profile considering operating risk, initial financial leverage, and subsequent redemption of debt. In several transactions, meaningful additional "add-on payments" occurred in subsequent financing rounds as well as premature disbursements. These payments influence the investor's exposure and the internal rates of return on the particular transactions. Staged investments usually have a lower risk than the initial payment given the debt redemption that takes place until the moment of the add-on payment. Similarly, premature disbursements or large dividends financed by recapitalizations usually have a higher risk than at the end of the holding period. To accurately track the risks of these buyouts with the mimicking investments, all underlying cash flows have to be matched. Our sample transactions show the following characteristics, exhibited in Table 1: The first transaction was closed in November 1984 and the last was exited by June 2004: 16 transactions were closed in the 1980s, 31 in the early 1990s and 74 in the late 1990s, while the remaining were closed in the new millennium. The holding periods range from three months to 15 years plus one month. The average and the median holding period are below four years, respectively. The equity stakes range from 8\% to 100\% ownership, where the average (median) is $76 \%(86 \%)$. This figure in general reflects the strategy of securing majority-voting rights in target companies in order to be able to control them effectively. The minor equity stakes in a few transactions represent syndicated equity layers.

\section{Table 1}

Descriptive Statistics of Sample Data

\begin{tabular}{|l|r|r|r|r|r|}
\hline & \multicolumn{1}{|c|}{ Min } & \multicolumn{1}{c|}{ Max } & \multicolumn{1}{c|}{ Average } & Median & Std. Dev. \\
\hline Closing Date & Nov 84 & Mar 03 & Nov 95 & Jul 96 & \\
\hline Exit Date & Feb 88 & Jun 04 & Jul 99 & Dec 99 & \\
\hline Holding Period [years] & 0.25 & 15.08 & 3.75 & 3.08 & 2.61 \\
\hline Equity Stake at Closing & $8 \%$ & $100 \%$ & $76 \%$ & $86 \%$ & 0.25 \\
\hline Equity Stake at Exit & $8 \%$ & $100 \%$ & $74 \%$ & $86 \%$ & 0.27 \\
\hline Initial Debt/Equity & 0 & 17.05 & 2.94 & 2.49 & 2.75 \\
\hline Exit Debt/Equity & 0 & 14.09 & 1.28 & 0.64 & 1.99 \\
\hline Enterprise Value at Closing [\$m] & 3.50 & $\begin{array}{r}\text { almost } \\
9,000\end{array}$ & 313.52 & 88.00 & 870.17 \\
\hline Enterprise Value at Exit [\$m] & 0.001 & $\begin{array}{r}\text { almost } \\
13,500\end{array}$ & 547.90 & 135.00 & $1,366.82$ \\
\hline Equity Investment [\$m] & 0.20 & $\begin{array}{r}\text { almost } \\
1,150\end{array}$ & 53.39 & 18.70 & 115.79 \\
\hline Final Payoff [\$m] & 0.001 & $\begin{array}{r}\text { almost } \\
1,800\end{array}$ & 160.38 & 63.10 & 299.05 \\
\hline IRR (p.a.) & $-100.00 \%$ & $\begin{array}{r}472.00 \% \\
\hline\end{array}$ & $50.08 \%$ & $35.70 \%$ & 0.92 \\
\hline
\end{tabular}


Regarding the degrees of financial leverage, the average (median) debt to equity ratio is 2.94 (2.49) at closing, and 1.28 (0.64) at exit. Some of the transactions do not include any debt. However, some of the buyouts are highly levered with degrees up to 17.05 . The high average and median degree of financial leverage found in our sample emphasizes the need to consider the effect of leverage risk in the performance assessment.

While at closing, the enterprise values of the target companies range from $\$ 3.5$ million to almost $\$ 9,000$ million, the average (median) is $\$ 313.5$ million ( $\$ 88.0$ million). At exit, the enterprise values range from $\$ 0.001$ million (a write off) to almost $\$ 13,500$ million with an average (median) of $\$ 547.9$ million ( $\$ 135.0$ million). Similarly, the amount of equity invested ranges from $\$ 0.2$ million in a small and syndicated transaction to almost $\$ 1,150$ million signaling the large exposure in certain transactions. On average (median) the amount of equity invested is $\$ 53.4$ million ( $\$ 18.7$ million). The final payoffs range between \$0.001 million (a write off) and almost $\$ 1,800$ million with an average of $\$ 160.4$ million and a median of $\$ 63.1$ million.

The descriptive statistics further reveal the diversity of the transactions made by the buyout funds, e.g., with holding periods ranging from three months to 15 years or equity exposure between $\$ 0.2$ million and $\$ 1,150$ million. With respect to transaction size and the observed financial structures, our sample can be regarded as "typical" compared to other samples, such as DeAngelo and DeAngelo (1987), Kaplan and Stein (1990 and 1993), Muscarella and Vetsuypens (1990), and Axelson, Jenkinson, Strömberg and Weisbach (2007).

The internal rates of return gross of fees range from $-100 \%$ (total write off within a year) to as high as $472 \%$ p.a. However, the mean average IRR of all the transactions and the median are $50.08 \%$ p.a. and $35.70 \%$ p.a., respectively. Since these figures do not consider differences in either the amounts invested or their duration, we also calculate the aggregate IRR over all the underlying cash flows, which is $33.19 \%$ p.a. This corresponds to the gross return an investor would have gained by participating in all of our sample transactions in an equal proportion of the equity values. We also calculate the invested-capital-weighted IRR of all the cash flows, which is 30.95\% p.a. These figures seem high, but are reported gross of all fees. The final returns to investors are much lower after deducting the fees typically paid in this asset class. Usually fees are structured as an annual percentage of the capital under management ('management fee' of 1-4\%) plus a performance related share ('carried interest' of 15\%-35\% of the returns), which is often subject to a hurdle rate. Alternatively, the management fee might be payable on invested funds. Anyway, fee structures are opaque and incomparable, as catch-up clauses might protect LPs from deteriorating returns over the life time of the fund, or as the timing of the carry payment also affects the final returns to investors. ${ }^{3}$

As detailed information about the entire population of buyout investments is unavailable, we can only speculate whether our sample represents typical transaction sizes, transaction structures, leverage ratios, sourcing or exit channels, or preferred industry segments at the time. At least, the ratios and dimensions of our sample transactions are very similar to those from other researchers, as discussed above. However, given the long sample horizon - from 1984 to 2004 - it should be stressed that trends, market conditions, debt interest rates and disclosed

\footnotetext{
3 A comprehensive description and discussion of compensation models can be found in Bygrave, Fast, Khoylian, Vincent, and Yue (1985), p. 96; Jensen (1989a), p. 68 and (1989b), p. 37; Sahlman (1990), p. 491; Murray and Marriott (1998), p. 966; Gompers and Lerner (1999a, p. 57 and 1999b), p. 7; Metrick (2006); Metrick and Yasuda (2008), and Phalippou (2009).
} 
returns on buyout transactions changed significantly within that period. The entire capital market segment passed two cycles, as reported by Gompers and Lerner (1999a and 2000). However, the temporal composition of our sample with 16 transactions from the 1980s, 31 from the early 1990s, 74 from the late 1990s and the remainder after 2000 represents the historical evolvement of the asset class.

Available datasets on PE transactions (such as Thomson Venture Economics or Venture0ne) usually do not contain any economic information other than the timing and the amount of cash flows. Additionally, it is impossible for us to trace our sample transactions in any one of these (and similar) databases, since they are kept anonymous. In general, our data gathering process is not determined by any economic variable but only by the facts that we first need to have a relationship with a research partner, and second the available PPM must provide sufficient information on the track records. Due to these facts and the impossibility of tracing our sample transactions in any other database, we unfortunately cannot quantify the extent to which our sample is biased through sample attrition. We rely on the data provided by the PPM as a single but primary and reliable source. It should be noted that the information provided is based on audited numbers and audited transactions.

Given the source of our data, there are good reasons for suspecting an upward return bias in our sample. First, we have to consider a possible selection bias arising from the GPs' reporting policy. GPs have an incentive to provide detailed information only for their successful transactions in the PPM, which is primarily a marketing instrument for fundraising. Second, we have to expect a survivorship bias based on the mechanism that unsuccessful GPs will find it difficult or even impossible to raise another fund. Hence, they will never write a PPM that reports their past unsuccessful investments. A sample like ours, which is derived from PPM information, will therefore be systematically biased towards the more successful fund managers that 'survive'. We address this issue in the next section after the introduction of our mimicking approach, and after the presentation of the results.

\section{The Mimicking Portfolio of the Buyouts}

To assess the opportunity cost of capital for buyouts, we create a mimicking portfolio of public market investments. These investments are designed to replicate the risk profile of the buyouts in terms of their timing and their systematic risk.

The determination of the mimicking portfolio requires for each buyout: a) the identification of a peer group of publicly traded companies with the same operating risk; b) the calculation of the equity betas for each of these 'public peers'; c) the unlevering of these beta factors to derive their operating or unlevered betas; $d$ ) the determination of a market weighted average of these operating betas for every peer group; and e) the re-levering of these peer group operating betas on the level of the buyout transactions at closing, and exit. The unlevering and re-levering procedures also require the specification of the risk, which is borne by the lenders, the risk of tax shields, as well as an applicable corporate tax rate.

With the individual buyout betas the mimicking portfolio can be established as follows: for every buyout transaction, an equal amount of equity is invested in a market proxy-portfolio which is levered up with borrowed funds until it matches the equity beta factor of the buyout at closing. If the buyout's beta is lower than 1, funds can be lent. The timing of the mimicking investments corresponds to the closing dates. The risk of the public market transaction is then adjusted every year, tracking the risk of the buyouts. Therefore, every position is liquidated 
annually, interest is paid, debt is redeemed and the residual equity is levered up again with borrowed funds (respectively funds are lent) to the prevailing systematic risk of the buyout. At this point, the value of the equity might have approached zero. This triggers default of the mimicking transaction and its return is calculated up to this point. The procedure is repeated until the exit date (for the "no default cases"). Then, the position is closed and, after serving debt, we receive a residual cash flow to the investor, which represents the final payoff. We can easily calculate the returns of these cash flows which represent the opportunity cost of capital of the buyouts.

The individual steps and the necessary assumptions used to construct the mimicking portfolio are discussed in detail in the Appendix. The approach enables the analyses described in the following section.

\section{Analyses and Results}

First, we can compare the leverage pattern of buyouts with that of their publicly quoted peers (see Table 1). With respect to leverage risk, we find that at closing the average debt/equity ratio of the buyout investments is 2.94 and their median is 2.49 . At exit those ratios are 1.28 (mean average), and 0.64 (median) respectively. In comparison, the mean average leverage ratio of all quoted peers over the five years is 1.38 , while the median is 0.83 . That means that on average our sample transactions are initially levered more than twice as much as their public peers. When exited, the target companies have even lower leverage ratios than their public peers. This finding should be contrasted with the literature. Ljungqvist and Richardson (2003) argue that buyout transactions create excess value as long as they don't use less than 0.476 the amount of equity used by their quoted peers under the conservative assumption of risk-free debt. We show that, while this ratio is initially 0.47 , it rises to 1.08 , and hence is 0.77 on average between closing and exit of a transaction. This, and the introduction of risky debt, would have increased the level of outperformance found in Ljungqvist and Richardson (2003).

Second, we take a look at the operating risk and find that the resulting unlevered beta factors range between 0.32 ( 0.05 percentile) and 1.40 ( 0.95 percentile). The mean average of the unlevered beta factors is 0.67 and their median is 0.56 . This is not surprising, as buyout fund managers typically choose low volatile businesses for their investments and, hence, the unlevered beta factors of target companies should be low in general. ${ }^{4}$

Third, the resulting systematic risk of the transactions ranges between 0.32 ( 0.05 percentile) and 3.88 (0.95 percentile) at closing, with a mean of 1.40 and a median of 0.94 . At exit the equity betas are between 0.32 ( 0.05 percentile) and 2.80 ( 0.95 percentile), with a mean of 1.01 and a median of 0.71. From that, we can calculate an average beta factor for all the transactions and over the holding periods of 1.21. This signals the need for adjustment of an index portfolio when benchmarking buyout performance.

Fourth, we build the portfolio of mimicking investments. As we explain in detail in the Appendix, the construction of the adequate of mimicking investments depends on several

\footnotetext{
${ }^{4}$ See e.g. Jensen (1989a), p. 64; Smith (1990), p. 154, DeAngelo and DeAngelo (1987), Table 1, or Lehn and Poulsen (1989), p. 774. The lower end of the range of unlevered beta factors could also result from the selection of infrequently traded peers. We attempted to exclude this kind of peer from our selection. Our sensitivity analysis considers this case for its effect on our results.
} 
assumptions. These assumptions are stressed in the subsequent sensitivity analyses and robustness checks. We start with our "base case" approach, and one of its important features is the replication of the limited liability for each buyout. Hence, the only available collateral for every individual mimicking investment is the portfolio of the S\&P 500 shares which are bought on the margin. As a result, levering up the portfolio is possible only at the cost of a credit spread. As a source for the relevant spreads we refer to Altman and Pasternack (2006). However, borrowing is possible at the risk free rate.

In our first sensitivity analysis, we relax this assumption and observe the consequences if lending is possible at the same credit spread, suggesting that investors can buy risky bonds and the S\&P 500 portfolio. Subsequently, we abandon the establishment of limited liability for setting up the mimicking investments and allow both risk free borrowing and lending. The next sensitivity analysis replicates Kaplan and Schoar (2005), i.e., the mimicking investments timematch the S\&P 500 portfolio. The last sensitivity analysis replicates Phalippou and Gottschalg (2008), assuming for the unlevering/levering process initial debt/equity ratios of 3 and final debt/equity ratios at average industry levels, a corporate tax rate of 35\%, a debt beta of 0.25 for the buyouts and 0 for the public market, and no differentiation between the risks of debt tax shields in the quoted and unquoted market segment. Further, risk-free borrowing and lending is possible in this case.

The beta factors that result from our base case and the proposed sensitivity analyses are presented in Table 2 and the descriptive statistics as well as the check for appropriateness of the different mimicking approaches is presented in Table 3.

\section{Table 2}

Equity Betas for the Baseline Case and Four Scenarios

This table presents the most important descriptive statistics of the S\&P 500 equity beta factors at closing and at exit in our base scenario and in different sensitivity analyses

\begin{tabular}{|c|c|c|c|c|c|c|c|c|c|}
\hline \multirow[b]{2}{*}{ \# } & \multirow[b]{2}{*}{ Scenario } & \multicolumn{4}{|c|}{ Closing } & \multicolumn{4}{|c|}{ Exit } \\
\hline & & $\begin{array}{l}0.05 \\
\text { pct. }\end{array}$ & $\begin{array}{l}0.95 \\
\text { pct. }\end{array}$ & Mean & Median & $\begin{array}{l}0.05 \\
\text { pct. }\end{array}$ & $\begin{array}{l}0.95 \\
\text { pct. }\end{array}$ & Mean & Median \\
\hline $0-2$ & Base Cases & 0.32 & 3.88 & 1.40 & 0.94 & 0.32 & 2.80 & 1.01 & 0.71 \\
\hline 3 & Kaplan/Schoar (2005) & 1 & 1 & 1 & 1 & 1 & 1 & 1 & 1 \\
\hline 4 & $\begin{array}{l}\text { Phalippou/Gottschalg } \\
\text { (2008) }\end{array}$ & 0.32 & 4.36 & 1.50 & 1.03 & 0.32 & 1.70 & 0.82 & 0.73 \\
\hline
\end{tabular}




\section{Table 3}

Descriptives of the Mimicking Portfolio Returns and Regression Results of the Scenarios

This table presents the descriptive statistics of the annualized rates of return of the mimicking investments, regression results and the test whether the mimicking model is applicable for our base case analysis and for different scenarios.

\begin{tabular}{|c|c|c|c|c|c|c|}
\hline \# & Scenario & 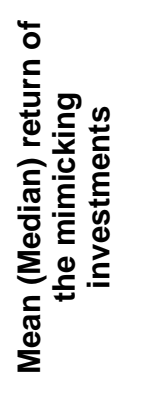 & 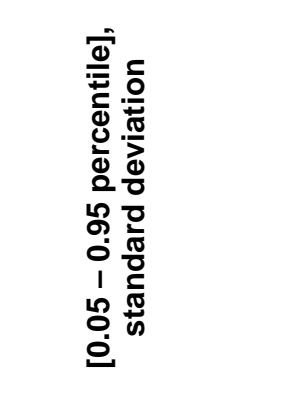 & 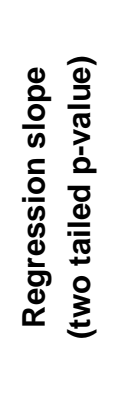 & ָ̃ & 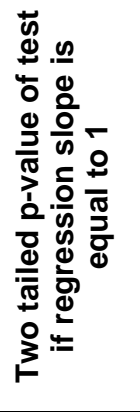 \\
\hline 0 & Base Case & $\begin{array}{r}9.07 \% \\
(12.16) \%\end{array}$ & $\begin{array}{r}{[-30.60 \%-38.25 \%]} \\
0.2525\end{array}$ & $\begin{array}{r}0.67 \\
(0.009)\end{array}$ & 0.034 & 0.195 \\
\hline 1 & $\begin{array}{l}\text { Base Case, but Borrowing and } \\
\text { Lending at Altman Spreads }\end{array}$ & $\begin{array}{r}10.30 \% \\
(13.91 \%)\end{array}$ & $\begin{array}{r}{[-29.50 \%-38.92 \%]} \\
0.2523\end{array}$ & $\begin{array}{r}0.65 \\
(0.011)\end{array}$ & 0.032 & 0.173 \\
\hline 2 & $\begin{array}{l}\text { Base Case, but Borrowing and } \\
\text { Lending at Risk Free Rate }\end{array}$ & $\begin{array}{r}12.89 \% \\
(12.59 \%)\end{array}$ & $\begin{array}{r}{[-22.93 \%-45.75 \%]} \\
0.2323\end{array}$ & $\begin{array}{r}0.63 \\
(0.025)\end{array}$ & 0.025 & 0.182 \\
\hline 3 & Kaplan/Schoar (2005) & $\begin{array}{r}12.36 \% \\
(14.95 \%)\end{array}$ & $\begin{array}{r}{[-13.88 \%-31.99 \%]} \\
0.1475\end{array}$ & $\begin{array}{r}1.46 \\
(0.001)\end{array}$ & 0.055 & 0.287 \\
\hline 4 & Phalippou/Gottschalg (2008) & $\begin{array}{r}12.55 \% \\
(12.60 \%)\end{array}$ & $\begin{array}{r}{[-26.31 \%-43.46 \%]} \\
0.2208\end{array}$ & $\begin{array}{r}0.71 \\
(0.015)\end{array}$ & 0.029 & 0.322 \\
\hline
\end{tabular}

To confirm the applicability of the mimicking approaches we test them like simple benchmark models, using the returns achieved in the buyout transactions as dependent variables and the returns of the mimicking investments as independent variables:

$\tilde{r}_{B O}=\alpha_{0}+\alpha_{1} \tilde{r}_{\text {Mimicking }}+\widetilde{\varepsilon}$

where:

$\tilde{\mathbf{r}}_{\mathrm{BO}}$

Returns of the buyout cash flows

$\tilde{\mathrm{r}}_{\text {Mimicking }}$

Returns of the mimicking investments

$\alpha_{0} \quad$ Intercept of the regression

$\alpha_{1} \quad$ Slope of the regression

$\tilde{\varepsilon} \quad$ White noise error term

If our benchmark models are appropriate to explain the buyout returns, the slope $\alpha_{1}$ should be equal to one, while the intercept $\alpha_{0}$ is rather meaningless due to the assumed bias towards high buyout returns gross of fees and a high influence of white noise in this regression. Hence, we test the hypotheses: $\mathrm{H}_{0} \rightarrow \alpha_{1}=1, \mathrm{H}_{1} \rightarrow \alpha_{1} \neq 1$. 
Our base case approach yields a mean average return of the mimicking investments of 9.07\%, and the median is $12.16 \%$. The 0.05 and the 0.95 percentile are $-30.06 \%$, and $38.25 \%$ respectively, while the standard deviation is 0.2525 . In our base case approach, we assume that lending is possible at the risk free rate and borrowing at the cost of high yield debt. This adequately replicates the limited liability in buyouts. For a fair comparison, the investor mimicking the buyouts should not borrow on his other assets. As a consequence, the cost of borrowing to establish the mimicking portfolio increases to the level paid in the buyout transactions. Actually, the cost of the debt required to set up the mimicking transactions might even be larger than for the buyouts because buying stocks on the margin is very expensive. The test-result for applicability of our model is positive. The explained variance of $3.4 \%$ of the dependent variable is very little, but this is not surprising at the given high volatility of the buyout and the mimicking returns. The $\mathrm{R}^{2}$ will remain small unfortunately, for all of the subsequent regressions. However, the regression slope 0.67 is different from zero with a p-value of 0.009 , and not significantly different from 1 with a p-value of 0.195 . As a consequence, the proposed model is adequate for benchmarking buyouts.

In the first sensitivity analysis (\# 1), we also apply the same credit spreads for lending. This leads to an increase of the mean (median) return of the mimicking investments to $10.30 \%$ (13.91\% respectively). The whole distribution of mimicking returns is shifted towards positive results as would be expected. Ninety percent of the returns are between $-29.50 \%$ and $38.92 \%$, and the standard deviation of the returns remains almost unchanged at 0.2523 . The regression confirms that this mimicking approach is also appropriate.

In the next sensitivity analysis (\# 2), we allow for risk-free borrowing and lending. The mean (median) mimicking return increases to $12.89 \%$ (12.59\%) and the return distribution shifts further towards positive returns with the 0.05 percentile at $-22.93 \%$ and the 0.95 percentile at $45.75 \%$. The standard deviation of returns slightly reduces to 0.2323 and the regression results signal applicability of that approach.

For the first three scenarios, the beta factors to match in the public market do not change because we do not change any assumption regarding the unlevering/re-levering process for the buyouts; we only change assumptions that affect the mimicking portfolio. Next, we replicate Kaplan and Schoars' (2005) findings (scenario \#3), and set all beta factors equal to 1, hence, there is no borrowing and lending involved. This is in strong contrast to the betas in our baseline cases that vary substantially over time and across transactions. On average, the systematic risk of the Kaplan and Schoar (2005) mimicking portfolio is lower than the systematic risk in our case. We achieve a mean (median) $12.36 \%$ (14.95\%) return of the mimicking transactions. The standard deviation of returns decreases to 0.1475 and this correspondingly narrows $90 \%$ of the return observations between $-13.88 \%$ and $31.99 \%$. The regression confirms that matching the buyouts with the S\&P 500 directly is appropriate.

In the final scenario (\#4), we replicate Phalippou and Gottschalg (2008) and use their approach for the unlevering/levering process. Here, betas range between 0.32 ( 0.05 percentile) and 4.36 ( 0.95 percentile) at closing with a mean average of 1.50 and a median of 1.03 . The betas decrease until exit to a range between 0.32 ( 0.05 percentile) and 1.70 ( 0.95 percentile) with a mean of 0.82 and a median of 0.73 . We find that equity betas are slightly larger at closing and slightly smaller at exit compared to our base case approach. Assuming risk-free borrowing and lending to adjust the mimicking investments leads to a mean return of $12.55 \%$ and a median of $12.60 \%$. These results, and also the standard deviation of the returns of 0.2208 , are close to scenario \#2. The 0.05 to 0.95 percentile is $-26.31 \%$ to $43.46 \%$, and the regression analysis signals appropriateness of this approach. 
The scenarios confirm that buyout opportunity cost of capital is largely determined by the assumptions on the appropriate cost of and the returns on debt to establish the mimicking investments. Kaplan and Schoar (2005) suggest time-matching the buyout investments with S\&P 500 exposure. This approach needs no assumptions about the capital structure of the individual buyouts, nor about any unlevering and re-levering procedure, hence it does also not need any determination of the cost/return on debt to establish the mimicking investment. However, the approach implies that, on average, buyout companies correspond to the average of the companies that comprise the S\&P 500 index with respect to their business risk, their leverage, and their cost of debt. Further, the approach implies that, on average, the buyout leverage ratios do not change over time, or more precisely, follow the pattern of the S\&P 500 companies. If these preconditions are accepted, time-matching S\&P 500 investments represent the correct opportunity cost of capital for buyout transactions.

However, we claim that buyout transactions do not usually happen in risky industries, and differ with regard to leverage ratios, leverage cost, and deleverage patterns from the "average" S\&P 500 company. Hence, we claim that corrections are necessary to control for these differences and propose these corrections in the Appendix. The described procedure leads to a set of levered and unlevered purchases of the S\&P 500 Index portfolio. For the establishment of the mimicking portfolio, we have to specify the cost and the risk of debt. The simplest case is to assume that debt is risk free and borrowing and lending is possible at the risk-free rate, which is scenario \#2. As a result, we achieve an average opportunity cost of capital of $12.89 \%$ (median 12.59\%) which is, in fact, slightly different from the mean average 12.36\% (median 14.95\%) return in the Kaplan and Schoar (2005) case. The approach by Phalippou and Gottschalg (2008) leads to $12.55 \%$ (median 12.60\%) which is very close to our result. One could conclude that the mentioned differences with respect to operating risks, leverage ratios and cost, net out on average. Hence, proper adjustments are not required, and the S\&P 500 may serve as a benchmark for buyouts, even if the large dispersion of returns suggest that every single buyout should be benchmarked with "its specific" opportunity cost of capital.

However, results change if we include a credit spread for the establishment of the mimicking transactions as we do in our base line case and scenario \#1. If we assume that the limited liability in buyouts is a valuable feature that shall also be replicated, the risk and the cost of debt will rise. The S\&P 500 portfolio must be purchased on the margin. In practice, it is in fact doubtful that banks allow borrowed share purchases up to the risk-levels that we detect at closing of some buyout transactions. This underlines the necessity to choose a fair mimicking approach that controls for this issue. As a consequence, we introduce risky debt to lever up the investments into the S\&P 500 index, and observe a strong decrease of the average return of the mimicking portfolio to $9.07 \%$ (median 12.16\%). This decrease is not surprising at first sight, as positive returns of the index portfolio are eaten up by the cost of debt. However, there is another factor that explains the deterioration of the average return. This is the simple fact that some of the mimicking transactions default. Thereby, it is not the transactions with the largest initial leverages. It is those with "bad" market timing that would have defaulted in the public market. If we also allow for lending at the same rates, the average return of the mimicking transactions becomes 10.30\% (median 13.91\%).

As a result, we claim that it is, first, not appropriate to use the unadjusted index portfolio as a benchmark. Second, adjusting for different operating and leverage risks requires certain specifications, as described in the Appendix. Third, a fair replication of buyouts with public market securities should consider the limited liability of the transactions that come at some cost: Buyout sponsors do not borrow on the buyout fund's other assets; the target corporations

IESE Business School-University of Navarra - 15 
borrow on their own assets. Hence, the equivalent approach is to purchase stocks on the margin.

In a next step, we control for our assumptions regarding the risk-adjustment process and analyze the influence of outliers on the calculations in robustness checks.

\section{a) Robustness Checks}

For all of our robustness checks, we assume riskless borrowing and lending when setting up the mimicking portfolio, for better comparison. However, we alter the assumptions for the unlevering/re-levering approach that determine the beta factors which have to be tracked in the public market. The resulting beta factors in the robustness checks, the returns, and the regression analyses are presented in Tables 3 and 4.

\section{Table 4}

Equity Betas for the Robustness Checks

This table presents the most important descriptive statistics of the equity beta factors at closing and at exit of our robustness checks.

\begin{tabular}{|c|c|c|c|c|c|c|c|c|c|}
\hline \multirow[b]{2}{*}{ \# } & \multirow[b]{2}{*}{ Robustness Check } & \multicolumn{4}{|c|}{ Closing } & \multicolumn{4}{|c|}{ Exit } \\
\hline & & $\begin{array}{l}0.05 \\
\text { pct. }\end{array}$ & $\begin{array}{l}0.95 \\
\text { pct. }\end{array}$ & Mean & Median & $\begin{array}{l}0.05 \\
\text { pct. }\end{array}$ & $\begin{array}{l}0.95 \\
\text { pct. }\end{array}$ & Mean & Median \\
\hline 1 & Industry Mix & 0.35 & 1.46 & 0.78 & 0.70 & 0.35 & 1.46 & 0.78 & 0.70 \\
\hline 2 & Leverage Only & 0.93 & 4.16 & 2.11 & 1.92 & 0.87 & 2.65 & 1.40 & 1.13 \\
\hline 3 & Increased Operating Betas & 0.45 & 5.87 & 2.22 & 1.70 & 0.43 & 3.90 & 1.50 & 1.09 \\
\hline 4 & Risk Free Debt & 0.69 & 6.39 & 2.57 & 1.99 & 0.47 & 3.88 & 1.53 & 1.07 \\
\hline 5 & Reduced Operating Risk & 0.24 & 2.35 & 0.83 & 0.45 & 0.24 & 1.95 & 0.66 & 0.44 \\
\hline 6 & Increased Risk of Debt & 0.32 & 3.36 & 1.19 & 0.72 & 0.32 & 2.68 & 0.92 & 0.65 \\
\hline 7 & Outliers Dropped & 0.31 & 3.89 & 1.32 & 0.91 & 0.31 & 3.12 & 1.01 & 0.70 \\
\hline
\end{tabular}




\section{Table 5}

Mean IRRs of the Mimicking Portfolios and Regression Results of Robustness Checks

This table comprises the descriptive statistics of the annualized rates of return of the mimicking investments, regression results and the test whether the mimicking model is applicable for the robustness checks.

\begin{tabular}{|c|c|c|c|c|c|c|}
\hline \# & Robustness Check & 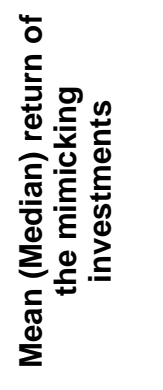 & 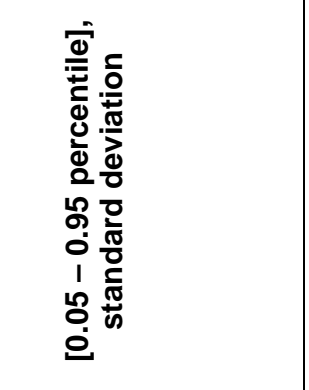 & 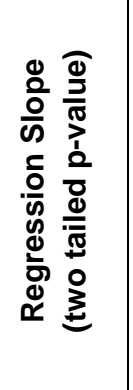 & $\tilde{x}$ & 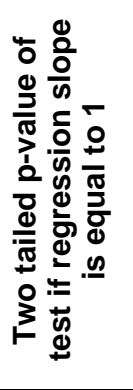 \\
\hline 1 & Industry Mix & $\begin{array}{r}10.12 \% \\
(11.97 \%) \\
\end{array}$ & $\begin{array}{r}{[-11.95 \%-27.86 \%]} \\
0.1253 \\
\end{array}$ & $\begin{array}{r}1.57 \\
(0.002) \\
\end{array}$ & 0.046 & 0.262 \\
\hline 2 & Leverage Only & $\begin{array}{r}17.72 \% \\
(19.60 \%) \\
\end{array}$ & $\begin{array}{r}{[-24.83 \%-56.21 \%]} \\
0.2653 \\
\end{array}$ & $\begin{array}{r}0.77 \\
(0.002) \\
\end{array}$ & 0.049 & 0.327 \\
\hline 3 & Increased Operating Risk & $\begin{array}{r}15.70 \% \\
(16.27 \%) \\
\end{array}$ & $\begin{array}{r}-40.41 \%-67.25 \%] \\
0.3501 \\
\end{array}$ & $\begin{array}{r}0.46 \\
(0.012) \\
\end{array}$ & 0.031 & 0.004 \\
\hline 4 & Risk Free Debt & $\begin{array}{r}17.57 \% \\
(18.13 \%) \\
\end{array}$ & $\begin{array}{r}{[-42.13 \%-72.35 \%]} \\
0.3534 \\
\end{array}$ & $\begin{array}{r}0.53 \\
(0.004) \\
\end{array}$ & 0.041 & 0.009 \\
\hline 5 & Reduced Operating Risk & $\begin{array}{r}10.11 \% \\
(10.07 \%) \\
\end{array}$ & $\begin{array}{r}{[-16.07 \%-31.51 \%]} \\
0.1468 \\
\end{array}$ & $\begin{array}{r}0.93 \\
(0.036) \\
\end{array}$ & 0.022 & 0.876 \\
\hline 6 & Increased Risk of Debt & $\begin{array}{r}11.86 \% \\
(11.65 \%) \\
\end{array}$ & $\begin{array}{r}{[-22.47 \%-41.21 \%]} \\
0.2106 \\
\end{array}$ & $\begin{array}{r}0.67 \\
(0.029) \\
\end{array}$ & 0.024 & 0.285 \\
\hline 7 & Outliers Dropped & $\begin{array}{r}12.27 \% \\
(12.01 \%) \\
\end{array}$ & $\begin{array}{r}{[-21.96 \%-45.37 \%]} \\
0.2290\end{array}$ & $\begin{array}{r}0.70 \\
(0.002) \\
\end{array}$ & 0.056 & 0.186 \\
\hline
\end{tabular}

The first robustness check (\#1) controls for the industry mix. We apply the average equity beta factors of our peer groups directly to the mimicking investments without considering different degrees of leverage. This leads to partial risk adjustment as such a mimicking portfolio replicates the industry mix of our buyouts but fails to capture the effect of (additional or less) leverage. In other words, the buyouts are benchmarked with their public peers directly. The approach leads to equity betas between 0.35 (0.05 percentile) and 1.46 (0.95 percentile) that remain constant over the holding period. Their mean average is 0.78 , and the median is 0.70 . Thus, the betas are lower than both the market beta and that of our baseline case. This results in a mean (median) return of the mimicking portfolio of $10.12 \%$ (11.97\%). The standard deviation of 0.1253 is the lowest of all of our different analyses, and this is mirrored in a narrowed 0.05 to 0.95 percentile, which is $-11.95 \%$ to $27.86 \%$. The regression proves the applicability of that approach.

This robustness check underlines two important implications: the average peer group betas are smaller than one, signaling that buyout funds search for targets in less risky industries. Further, we see again that without taking into account leverage risks, the opportunity cost of buyouts become low, at least lower than in Kaplan and Schoar (2005). 
In the second robustness check (\#2), we examine the impact of leverage alone on returns. We set all the investments of the mimicking portfolio to have an unlevered beta of 0.84 (which is the unlevered beta factor of the S\&P 500 Index). Here we draw on data provided by Bernado, Chowdhry and Goyal (2004), which determines unlevered beta factors for the Fama and French (1997) industry classification. ${ }^{5}$ We then lever up each mimicking investment with the actual leverage of the corresponding buyout. This leads to a comparison of the buyouts with a levered- and time-matched investment in a hypothetically leverage-free public market index. This scenario adjusts for differences in leverage risk, but not for the impact of different operating risks in the chosen industries.

The resulting betas range at closing from 0.93 ( 0.05 percentile) to 4.16 ( 0.95 percentile) with a mean average of 2.11 and a median of 1.92. At exit they are between 0.87 ( 0.05 percentile) and 2.65 ( 0.95 percentile) with a mean of 1.40 and a median of 1.13 . Thus the betas are larger, on average, than in our baseline case. This highlights once more the proposition that buyout fund managers search within low-risk industries. Corresponding with the higher beta factors, the mimicking portfolio yields a mean (median) return of $17.72 \%(19.60 \%)$. The standard deviation of returns becomes as high as 0.2653 and the 0.05 to 0.95 percentile is $-24.83 \%$ to $56.21 \%$. The regression signals appropriateness of the approach.

The third robustness check (\#3) controls for the sensitivity of our results with respect to the calculation of the operating betas for the peer group companies. Buyout transactions often take place in niche markets in which shares might be traded infrequently. As several studies have found, infrequently traded assets do not closely follow market movements (Fisher, 1966; Pogue and Solnik, 1974; Scholes and Williams, 1977; Schwert, 1977, and Dimson, 1979). As a result, the business risks of the target companies could be downward biased. Along the same lines, one could argue that our approach inherently leads to a lower risk boundary for the buyout transactions, as we use comparables transferred from the public market to the unquoted segment. Another reason to perform this check is that we might have miss-specified the risk of debt, of debt tax shields, or the applicable tax rate in our unlevering/re-levering approach (as described in the Appendix).

Hence, we increase the operating risk of each of the investments in the mimicking portfolio arbitrarily by an arbitrary factor that corrects for a suspected 25\% understatement of the operating betas in our calculations. Consequently, the resulting equity betas increase (in reference to our baseline case) within the range of 0.45 ( 0.05 percentile) to 5.87 ( 0.95 percentile) at closing, with a mean of 2.22 and a median of 1.70. At exit, they range from 0.43 (0.05 percentile) to 3.90 (0.95 percentile) with a mean of 1.50 and a median of 1.09 .

As expected, the mean (median) return of the mimicking investments increases to $15.70 \%$ (16.27\%). The standard deviation of returns becomes as high as 0.3501 , which expands the 0.05 to 0.95 percentile to $-40.41 \%$ to $67.25 \%$. However, the regression slope of 0.46 is significantly different from 1 at a p-value of 0.004 . Hence, this seems not to be an appropriate benchmarking approach.

In the following robustness check (\#4), we control for the impact of the risk of debt. As explained in detail in the Appendix, we use a debt beta of 0.41 in our base case analysis to lever-up the buyout betas. In this check, we instead replicate our calculations using risk-free debt. When no risk can be transferred to the lenders, all the leverage risk is borne by the equity

\footnotetext{
${ }^{5}$ See Bernado, Chowdhry and Goyal (2004), Table 1, panel C, means of 1978-2002 data column.
} 
sponsors, and therefore, the equity betas for our mimicking transactions increase substantially. They range at closing from 0.69 (0.05 percentile) to 6.39 ( 0.95 percentile), with a mean of 2.57 and a median of 1.99. At exit they range from 0.47 ( 0.05 percentile) to 3.88 ( 0.95 percentile), with a mean of 1.53 and a median of 1.07 respectively.

Accordingly, the mean (median) return of the mimicking investments rises to peaking $17.57 \%$ (18.13\%). These peaks are mirrored by the dispersion of returns. The standard deviation becomes 0.3534 , and $90 \%$ of the returns are between $-42.13 \%$ and $72.35 \%$. One can conclude that if buyout sponsors are not able to transfer risks to the lenders, the appropriate opportunity cost of capital becomes very large and dispersed. However, the assumption that lenders in buyout transactions to not take risks is rather hypothetical. Additionally, the regression results suggest that assuming risk-free buyout debt is not appropriate when benchmarking buyouts: The slope of 0.53 is significantly different from one at the 0.009 level.

The next robustness check (\#5) follows Kaplan and Stein (1990), and we assume that operating improvements have lowered operating risk. A reduction of operating risks might, for example, be caused by improved governance by the active investors. Thus, we (arbitrarily) reduce all the operating beta factors by $25 \%$. This reduction of operating beta factors could also be justified by an overestimation of the risk of investment-grade debt, and an underestimation of the corporate tax rate while initially calculating the operating beta factors. However, this also leads to a lower truncation level for the risk of debt and hence lower levered mimicking investments (see the Appendix). Accordingly, the beta factors for this scenario shrink to between $0.24(0.05$ percentile) and 2.35 (0.95 percentile), with a mean (median) of only $0.83(0.45)$ at closing. They decrease to a range between 0.24 (0.05 percentile) to 1.95 (0.95 percentile), with a mean (median) at $0.66(0.44)$.

Due to the resulting low beta factors the mean (median) return of the mimicking investments is only $10.11 \%(10.07 \%)$. The standard deviation is also low at 0.1468 , while $90 \%$ of the return distribution is between $-16.07 \%$ and $31.51 \%$. The regression slope is 0.93 and hence close to one. This confirms the applicability of this approach, and turns to its discussion: If buyout sponsors are indeed able to lower the operating risks of their portfolio companies by enhanced governance or restructuring activities, they likewise decrease their opportunity cost of capital. Improved governance by the active investor is named in Jensen (1989a and 1989b), Kaplan (1989a and 1989b), Lichtenberg and Siegel (1990), Smith (1990), and Kaplan (1991) as a particular determinant in buyout transactions. Hence, these improvements should be accounted for in buyout performance analyses.

In our sixth robustness check we analyze what happens if lenders take on an even higher proportion of risk than that assumed in our baseline case. This assumption is also reasonable as high yield bonds or mezzanine funding is often extensively used to structure buyout transactions. It is also consistent with prior research that found even higher debt betas for buyouts (such as Kaplan and Stein (1990)). Hence, we arbitrarily increase our debt beta to 0.50 to lever up the mimicking investments.

The resulting equity betas range from 0.32 ( 0.05 percentile) to 3.36 ( 0.95 percentile) at closing, with a mean of 1.19 and a median of 0.72 . At exit, the betas range from 0.32 ( 0.05 percentile) to 2.68 ( 0.95 percentile), with a mean of 0.92 and a median of 0.65 . As more risk is transferred to the lenders, the mean (median) return of the mimicking investments decreases (compared to our base case analysis) to $11.86 \%$ (11.65\%). The standard deviation of returns is 0.2106 and the $0.05-0.95$ interval ranges from $-22.47 \%$ to $41.21 \%$. The regression slope of 0.67 is not 
significantly different from one. This leads us to conclude that the opportunity cost of capital of buyout transactions becomes smaller if we assume that GPs are able to structure buyout transactions transferring a substantial part of the transaction risk to the lenders. This is a common feature in buyout transactions where debt layers are often provided against insufficient or no collateral.

In the final robustness check we exclude those transactions from our sample that could be considered "atypical" or outliers of other buyout transaction. Even with full data regarding the transactions, some would be characterized by relatively low or zero leverage ratios, minority ownership of the active investor, or either very short, or long holding periods. Hence, we exclude transactions from our sample with a debt/equity ratio below 0.25 and where the institutional investors' equity ownership is below 50\%. We further exclude transactions with holding periods below a year and above nine years. Finally, we exclude the most successful transactions with achieved internal rates of return above $200 \%$ p.a. This results in a reduced sample of 108 transactions. The equity betas then range between 0.31 ( 0.05 percentile) and 3.89 ( 0.95 percentile) at closing, with a mean of 1.32 and a median of 0.91 . At exit, the betas range from 0.31 (0.05 percentile) to 3.12 (0.95 percentile) with a mean (median) of 1.01 (0.70). The mimicking portfolio yields a mean (median) return of 12.27\% (12.01\%) which is slightly lower than in our baseline case, assuming borrowing and lending at the risk-free rate. The standard deviation of returns is 0.2290 , while the 0.05 to 0.95 interval is from $-21.96 \%$ to $45.37 \%$. The regression slope of 0.70 is not significantly different from one. Hence, dropping "outliers" from our sample of transactions does not meaningfully change the results.

\section{b) Sample Selection Bias}

To analyze the extent of a sample selection bias with respect to the success of the transactions, we first study the impact of fees on the returns of our sample buyouts, and recalculate the internal rates of return achieved in the buyout transactions after deducting carried interest. Therefore, we assume expensive GPs, charging 30\% carried interest at a hurdle rate of $0 \%$. The average (median) internal rate of return of our sample transactions reduces from $50.08 \%$ to 35.50\% (median from 35.70\% to 27.85\%). These were the average (median) IRRs achieved by investors if management fees were already paid. However, the management fees lower the amount of money available for investments, no matter if paid on committed or invested capital. Phalippou (2009) argues that a typical buyout fund charges the equivalent of 7 percent fees per year. This calculation includes management fees, and carried interest, among other fee components. His analyses are based on committed capital and not invested. For our transactions, we only know how much money was invested but not how much was committed. Metrick and Yasuda (2008) provide an illustrative example where total management fees add up to $14.81 \%$ of nominal invested funds. ${ }^{6}$ Hence, we can correct for this discount and appreciate the cash outflows from the investors by $100 / 86.23$. This simplifying calculation leads to a mean (median) IRR of 25.92\% (23.59\%). Hence, the average internal rates of return after fees achieved in our buyout sample transactions are somehow higher than, for example, those reported by Kaplan and Schoar (2005), Phalippou and Gottschalg (2008), or Phalippou (2009).

A bias towards higher returns earned in our sample transactions does not harm our results as long as the achieved returns are independent of the parameters that determine the mimicking

\footnotetext{
${ }^{6}$ This is total management fees of $\$ 12.77$ divided by invested capital $\$ 86.23$ per $\$ 100$ committed, according to the numbers Metrick and Yasuda (2008) provide.
} 
investment. Therefore, we search for correlations between the IRRs achieved in the buyout transactions; and all determinants necessary to set up the mimicking portfolio. We find four significant correlations at the two-tailed 0.05 significance level: Achieved IRRs correlate positively with the degree of leverage at closing $(\rho=0.204)$, with debt redemption abilities $(\rho=$ 0.556), with the peer group's average beta factor $(\rho=0.211)$, and negatively with the holding period ( $\rho=-0.335$ ). Hence, as our sample is biased towards higher IRRs it might likewise be biased towards highly levered transactions, target corporations with strong free cash flows, risky peers, and short holding periods. However, we also verify if these parameters drive the returns of the mimicking portfolio in parallel. We find that only the initial degree of leverage ( $\rho$ $=0.240$ ) likewise positively affects buyout opportunity cost of capital.

We conclude that our sample might be biased towards highly levered transactions, and this increases the average opportunity cost of capital. Unfortunately, we cannot correct for this bias because initial leverage ratios are unknown for the population of buyouts. However, our observations are in line with the samples used by other researchers, such as DeAngelo and DeAngelo (1987), Kaplan and Stein (1990 and 1993), Muscarella and Vetsuypens (1990), and Axelson, Jenkinson, Strömberg and Weisbach (2007). Anyway, if we include too many highly levered transactions in our sample, the returns of the mimicking investments increase. Therefore, our calculations of opportunity costs of capital for buyout transactions represent upper estimates - and this does not harm the following overall conclusions.

\section{Conclusion}

In this paper, we contribute to the discussion of how to determine opportunity cost of capital for buyout transactions. For a set of 133 United States buyouts between 1984 and 2004, we propose a portfolio of levered mimicking investments in the S\&P 500 Index that match the buyouts with respect to the timing of their cash flows and their systematic risks. An approach like ours had not previously been used due to the non-availability of required data for the determination of the buyouts' systematic risks. With our rich data set, we show that using the returns of the S\&P 500 (or any other benchmark index) as opportunity cost of capital for buyout performance analyses only yields preliminary results. The risk pattern in buyout transactions is different from the public benchmark index. Usually, buyout transactions happen in less than average risky industries. Contrarily, they are levered up at closing to an extent that exceeds the risk of the market proxy. However, over the holding period this risk is reduced by amortization payments. Further, limited partners themselves do not borrow money to lever up their transactions. The required debt is borrowed by the target corporations, and the fund's liability is limited to its equity exposure. As a result, borrowing at the risk-free rate is a highly unrealistic assumption, when setting up a public market mimicking investment. We show that taking into account these issues leads to average (median) opportunity cost of capital which are $3.29 \%(2.79 \%)$ below the mean average (median) of the S\&P 500 returns. The average/median opportunity cost of capital of buyouts is ex post lower than the benchmark index due to the simple fact that if our sample of buyouts was appropriately mimicked in the public market, many of the transactions would have defaulted. However, it is not the most levered transactions that default - it is simply those transactions that are badly timed in the public market. A potential bias in our sample towards highly levered transactions does not affect this result because high leverage ratios affect the mimicking returns positively, hence, in the opposite direction. If we assume that borrowing and lending is possible at the risk-free rate to set up the mimicking investments, the mean buyout opportunity cost of capital becomes close to the result 
by Kaplan and Schoar (2005). However, there still remains a difference of 2.36\% regarding the median returns of both distributions. The standard deviation of returns remains much higher, again comparing our approach and Kaplan and Schoar (2005). As a result, we claim that buyouts should not be "averaged" for performance analyses. On the contrary, a comprehensive discussion of the inherent risks caused by the business and applied leverage ratios is necessary when judging buyout success. The discussion includes the question of how much risk is taken by lenders in these transactions, whether risks might be decreased due to improved governance, and what credit-spreads have to be paid when levering up the public market equivalent.

Our study builds on and extends existing work on the comparison of public and private equity performance in several respects:

First, we propose a method for benchmarking the asset class that might become an industry standard.

Second, our study exploits the detailed information available on a large sample of individual buyouts to illustrate the importance of a detailed risk-adjustment for assessment of their performance. Using precise information on the valuations of individual target companies, their competitors, as well as their industry sector and on the capital structures of the investment vehicles at the closing date and at exit, it becomes possible to attribute operating and leverage risk measures to each individual transaction. Thus, we can comprehensively control for the transaction risks in constructing a well-defined mimicking portfolio with an equal risk profile. The sensitivity analyses highlight the importance of a comprehensive risk-adjustment that considers both operating and leverage risks for an accurate assessment of buyout performance. This is directly relevant for interpreting findings from prior research where this kind of risk separation has not been possible.

Third, our study provides detailed insights into the importance of different assumptions regarding the risk-profile of debt, debt tax shields, credit spreads and transaction operational risks. The analyses confirm the conjecture that buyout investors choose industries with low operating risk, use financial leverage where favorable, and transfer an important portion of the risk to the lenders.

Absent detailed data on the risk characteristics of the entire universe of buyout transactions, any assessment of the relative performance of buyouts has to remain inconclusive. The detected differences regarding the distributions of returns in our base case analysis, and the scenarios and robustness checks are large. Researchers should thoroughly specify their presumptions with respect to the above discussed determinants when assessing buyout performance. 


\section{Appendix \\ Constructing the Mimicking Portfolio}

We take the perspective of a well diversified investor not exposed to idiosyncratic risks of the particular buyout transactions. Accordingly, timing and equity betas of the mimicking strategy have to correspond to those of the buyout transactions. To track the transactions, we construct an index portfolio and allow funds to be borrowed or lent. We assume that borrowing and lending is possible in unlimited amounts. However, the assumptions regarding the risks taken by lenders and different rates for borrowing and lending largely determine the returns of the mimicking investments. In our base case, we assume that lenders take risk and receive appropriate compensation. Contrarily, if the mimicking investment includes unlevering the index portfolio, funds are lent at the risk-free rate. In the course of robustness checks, we stress these assumptions to investigate the effect of credit spreads, and change the risk borne by lenders. We use the total return calculations for the S\&P 500 Index, provided by DataStream as the performance benchmark. This index assumes that dividends are reinvested, which accurately reflects the fact that, during buyout transactions, dividends are not usually paid but free cash flows are used for debt redemption. However, if there is a notable premature disbursement, it is considered. The exact approach to tracking the individual buyout transactions is described in the following.

\section{a) Framework}

For the theoretical background for our mimicking strategies we refer to Modigliani and Miller (1958), assuming that every company is exposed to some unavoidable and constant economic risk by its business. This risk has to be borne by the investors of a company. If a company is fully equity financed, the investors are directly exposed to that risk. If debt financing is used, risk is allocated to the equity investors and the debt providers according to ratios discussed below. For the purpose of our analysis, the constant risk class assumption means that a risk class shall be attributed to every target company defined by the operating risk of its public peers. This assumption merits discussion in general, ${ }^{7}$ but especially regarding buyouts. There, efforts are often made by management teams to reduce operating risks, e.g., by focusing on safer (i.e., less volatile) business strategies. ${ }^{8}$ However, we cannot correct for this kind of risk class transition because, first, we do not have sufficient information about the strategic activities of the target companies after closing; and second, we would be unable to assess how the activities had influenced the companies' business risk. For these reasons, we base our approach on the assumption of unchanging risk classes.

\footnotetext{
7 For early discussions of the constant risk class hypothesis refer to Ball and Brown (1967), who argue that, according to some typical ratios, different risk classes can be attributed to enterprises. Gonedes (1969) tests the constant risk class assumption. He finds some support to refute the hypothesis. Sharpe and Cooper (1972) investigate risk classes at the New York Stock Exchange and find evidence for the existence of constant risk classes.

8 Some evidence that target companies focus on less risky businesses after buyouts close is provided by Hite and Vetsuypens (1989), p. 959; Kaplan (1989a), p. 224; Lehn and Poulsen (1989), p. 776; Marais, Schipper, and Smith (1989), p. 167; Asquith and Wizman (1990), p. 197; Muscarella and Vetsuypens (1990), p. 1398; Palepu (1990), p. 248; Smith (1990), p. 145; Opler (1992), p. 28; Holthausen and Larcker (1996), p. 328; Bae and Simet (1998), p. 159; Elitzur, Halpern, Kierschnick, and Rotenberg (1998), p. 352; Nohel and Tarhan (1998), p. 197; Cotter and Peck (2001), p. 105; Holmstrom and Kaplan (2001), p. 127, and Bruton, Keels, and Scifres (2002), p. 713. The operating risk is thereby generally expressed by the steadiness of operating earnings or by the ratio between fixed costs and variable costs.
} 


\section{Appendix (continued)}

There are also practical reasons to assume constant risk classes since it is practically impossible to identify adequate peer group companies and obtain the necessary data for the time our sample transactions actually took place. Hence, we perform all the calculations for the business-class risks with present data. Therefore the peers' weekly stock prices and annual balance sheet data between 1999 and 2003 are used. The results are then transferred to the time of the actual transaction. In this way, we assume that typical business-class risks remain constant even over a very long time horizon.

\section{Unlevering the Peer Groups' Business Class Risks}

Since buyout transactions often occur in very particular niche markets, we do not want to rely on broad industry definitions to classify our sample transactions. Rather, we aim to be as precise as possible assigning peer groups to our 133 sample companies and identifying their 116 different industry sectors. Some of the transactions were made simply in the same business. For these industry sectors we determine peer groups of quoted comparable companies. A peer group is defined by an equal four-digit SIC code and by company headquarters in the United States. For some transactions, the principal competitors are named in the documents, thus facilitating the peer group analysis. The majority of the peers however, are defined by the description of the relevant market and the target companies' products/services. This approach leads to suitable peer group samples. An advantage of focusing on buyout transactions is that reasonably comparable quoted companies usually exist. The accuracy of the peer group selection is qualitatively verified by comparing the major business units and products of the peers and the targets. As an additional filter we require the peer companies to be traded regularly.

We decided that, in order to be meaningful, a peer group has to consist of at least three companies. For a few buyouts, we find more than 20 peer group members. In these cases, we narrow the search by including an appropriate company size in terms of market capitalization. We eliminate those companies from the peer group that are out of the range of 50\% to 200\% of the equity value of the target. We are aware that this approach excludes non-successful competitors with low market capitalization that might face operating difficulties or even bankruptcy. However, this is in line with our basic assumption of not incorporating nonsystematic risk such as bankruptcy. Finally, we identify 1,207 peers to be incorporated into our analysis.

We measure the business class risks for our transactions by a market-weighted average of the unlevered beta factors of the relevant peer group companies. To gain these beta factors, we calculate the actual levered beta factors of every single peer-group company using the S\&P 500 Index as a benchmark and weekly returns from January 1999 to December 2003. To unlever these beta factors, we determine leverage ratios of the companies during the same time from balance sheet and market data obtained from DataStream. Therefore we net total debt of each period (which includes short- and long-term interest bearing debt) by cash positions and divide it by the year-end market capitalizations (of straight and preferred equity). Finally, we determine the arithmetic average over the periods. Thus, we assume that the nominal value of balance sheet debt equals its market value. This implies that the beta factors reflect current leverage ratios, but do not anticipate them. Once we determined the arithmetic average of the 


\section{Appendix (continued)}

leverage ratios we use a beta transformation formula to derive the hypothetical beta factor for the company without any debt. Such a formula has to consider the role of the tax benefit of debt financing (the tax savings that result from deducting interest from taxable earnings). In the simplest case where debt is perpetual and risk free, the interest expense can always be fully deducted from the taxable earnings, and the tax rate and the interest rate do not change, the capitalized value of the tax shield simplifies to $\tau \mathrm{D}{ }^{9}$

While, in general, the assumption of unchanging risk classes has to be accepted, the postulate of debt being risk free should be stressed for our analysis to allow for real market conditions, such as credit risk on corporate bonds. Mandelker and Rhee (1984) present how operating company risk is borne by equity investors and risky debt providers according to the applied leverage ratio: ${ }^{10}$

where:

$$
\beta^{\mathrm{u}}=\frac{\beta^{\mathrm{e}}+\beta^{\mathrm{d}}(1-\tau) \frac{\mathrm{D}}{\mathrm{E}}}{1+(1-\tau) \frac{\mathrm{D}}{\mathrm{E}}}
$$

$\beta^{\mathrm{d}} \quad$ systematic risk borne by debt providers (debt beta)

$\beta^{\text {e }} \quad$ systematic risk borne by equity investors (levered equity beta)

$\beta^{\mathrm{u}} \quad$ systematic operating risk (unlevered beta)

$\tau \quad$ marginal tax rate

D market value of debt (all tax-deductible sources of capital such as senior, subordinated and mezzanine debt)

E market value of equity (common and preferred)

Having calculated a debt beta factor $\beta^{\mathrm{d}}$ (which is discussed later), and fixed the marginal tax rate at $35 \%,{ }^{11}$ we can calculate the unlevered beta factor for every single peer-group company applying its average debt-to-equity ratio. Finally, we determine the market capitalization weighted average of the unlevered beta factors of all the companies of a peer group. We refer to this as our measure for the systematic operating risk of the target companies. ${ }^{12}$

\footnotetext{
${ }^{9}$ This was originally derived by Modigliani and Miller (1958 and 1963), first empirically tested by Hamada (1972) and transferred into the CAPM by Rubinstein (1973). Refer to Drees and Eckwert (2000) for a critique of this approach.

${ }^{10}$ See Mandelker and Rhee (1984), Equation (3) and Footnote 2.

${ }^{11}$ See Graham (2000).

${ }^{12}$ A comprehensive discussion regarding degrees of operating and financial leverages and the implications on operating and equity beta factors is lead by Hamada (1972), Gonedes (1973), Lev (1974), Beaver and Manegold (1975), Hill and Stone (1980), Gahlon and Gentry (1982), Frecka and Lee (1983), Huffman (1983), Mandelker and Rhee (1984), Lee and Wu (1988), Healy and Palepu (1990) and Darrat and Mukherjee (1995).
} 


\section{Appendix (continued)}

\section{Levering Up the Individual Transactions}

Formula (2) reflects the assumption that uncertainty regarding the company's ability to gain the tax benefits from debt financing is best measured by the rate at which its creditors lend the money. This is the cost of debt $\mathrm{r}^{\mathrm{d}}$. As long as the leverage ratios are moderate, this seems to be the correct relationship between the systematic operating risk and the risk borne by the shareholders and lenders. If leverage ratios increase, the company may be unable to realize the tax benefits either fully or partially, simply because it does not generate sufficient income and will be unable to carry losses forward. ${ }^{13}$ The risk of not being able to fully profit from debt finance is then as high as the risk of obtaining the income itself (the operating systematic risk). Then, the more appropriate rate for discounting the tax benefits equals the unlevered cost of capital. ${ }^{14}$ The operating company risk is then borne by the equity and debt investors according to the following relationship: ${ }^{15}$

$$
\beta^{\mathrm{u}}=\frac{\beta^{\mathrm{e}}+\beta^{\mathrm{d}} \frac{\mathrm{D}}{\mathrm{E}}}{1+\frac{\mathrm{D}}{E}}
$$

We assume that, for the publicly quoted companies of our peer groups, the degrees of leverage are moderate and, therefore, the tax benefits are discounted by the cost of debt. We follow Kaplan and Ruback's (1995) argument regarding buyout transactions and capitalize the tax benefits by the operating cost of capital. Hence, we make use of Formula (3). This approach is based principally on two typical features of buyout transactions. First, on average, the amount of debt used in initiating a buyout leads to leverage ratios far higher than the average debt-toequity ratios of quoted companies. ${ }^{16}$ This results in a higher risk association with tax shields because the companies might not achieve enough income to fully benefit from the taxdeductible interest payments. Second, attempts are usually made to redeem debt levels as quickly as possible. Therefore, it is common to liquidate assets and to use free cash flows for debt service. ${ }^{17}$ This leads to uncertain future debt levels that depend on the future free cash flows and, hence, the uncertainty about future interest payments (as well as the tax benefits) is as high as the uncertainty about the operating business.

As discussed, the resulting equity beta factors are influenced by the assumption regarding the risk of achieving the future tax shields. Since some transactions in our sample have lower debt levels and therefore higher probabilities of benefiting from tax shields, it could be argued that

\footnotetext{
${ }^{13}$ See Modigliani and Miller (1963), Footnote 5.

${ }^{14}$ See the discussions about this topic in Myers (1974), p. 22; Riener (1985), p. 231; Myers and Ruback (1987), p. 9; Kaplan and Ruback (1995), p. 1062; Arzac (1996), p. 42, and Graham (2000), p. 1917.

15 See Ruback (2002), Equation 34.

${ }^{16}$ See De Angelo, De Angelo, and Rice (1984), p. 373; Marais, Schipper, and Smith (1989), p. 159; Kaplan and Stein (1993), Table 3; Cotter and Peck (2001), p. 105; Axelson, Jenkinson, Strömberg and Weisbach (2007), Table 6, and our Table 1.

${ }^{17}$ See Shleifer and Vishny (1992), p. 1362, and Kaplan and Stein (1993), p. 333.
} 


\section{Appendix (continued)}

Formula (2) is more appropriate at least for some of the transactions. Further, it could be argued that, in accordance with Kaplan (1989b), the tax benefits of buyout transactions are most meaningful to investors. Thus the investors ensure that the risk of receiving the tax benefits is rather low and, therefore, Formula (2) would again be the more appropriate to lever up the beta factors for the buyout transaction. Since both arguments seem rich, we consider both approaches in the sensitivity analysis, varying the resulting beta factors.

Again, after having specified the systematic risk of debt $\beta^{\mathrm{d}}$ (as described in the following section), we can calculate the equity betas for every single buyout and adjust them annually for the redemption abilities of the target companies. This provides ex post equity beta transition patterns between closing and exit for the individual transactions.

\section{Deriving Debt Betas}

We next need to specify the systematic risk of debt in order to be able to lever and unlever the systematic equity risk according to Formulas (2) and (3). We distinguish between the moderately levered publicly traded companies and the (in general) more highly levered buyout transactions. An adequate measure of the systematic risk of the debt layers of the quoted companies would be provided by the beta factor of investment grade debt. Due to different maturities and decreasing durations and, therefore, decreasing volatility over time, it is not clear which bonds would be best suited to measuring systematic debt risk. ${ }^{18}$ This problem is exacerbated when calculating a risk proxy for the buyout debt. Therefore low grade/high yield bonds would be the benchmark. These bonds usually have larger coupon payments, and are called, converted or defaulted more frequently than investment grade bonds. ${ }^{19}$ This leads to the problem that, on average, the duration and, hence, the volatility, might be even lower than for investment grade bonds. ${ }^{20}$

We follow Cornell and Green (1991) and calculate average debt beta factors from the price data of open-end bond funds. This resolves the issue of lacking price data on low-grade bonds, defaults, calls, and conversions. We retrieve weekly gross-returns and 2004 year-end market capitalizations for 314 open-end funds investing in investment-grade corporate debt and we retrieve the same data for 101 open-end bond funds investing in low-grade debt securities. ${ }^{21}$ Using the S\&P 500 Index as a market proxy over a two-year horizon, we calculate the beta factors for each fund. We then determine the market capitalization weighted average for the investment grade and for the high yield samples. For the investment grade sample, we determined a debt beta factor of 0.296 and of 0.410 for the high yield sample. Since the risk profile of our sample transactions is highly dependent on the assessment of the debt betas, we will perform a sensitivity analysis and include other research results on debt beta calculations.

\footnotetext{
18 See Fisher and Weil (1971), Boquist, Racette, and Schlarbaum (1975), Lanstein and Sharpe (1978), p. 657; Livingston (1978) and Cox, Ingersoll, and Ross (1979).

19 See Altman (1989), p. 913; Asquith, Mullins, and Wolff (1989), p. 928, and Blume, Keim, and Patel (1989), published (1991).

${ }^{20}$ See Cornell and Green (1991), p. 47.

${ }^{21}$ Data was retrieved from Bloomberg.
} 


\section{Appendix (continued)}

Blume, Keim, and Patel (1991) directly calculate betas with the S\&P 500 for different periods using Scholes and Williams' (1977) and OLS-regressions of returns on government bonds and on low-grade bonds with at least ten years to maturity. They find beta factors for the government bonds ranging between 0.16 and 0.83 and betas for the low-grade bonds of between 0.32 and 0.71 (less than the maximum of the government bonds!). Cornell and Green (1991) report debt betas for different bond risk classes and periods using bond fund returns. Their investment-grade debt betas range from 0.19 to 0.25 and their high-yield betas range from 0.29 to 0.54 .

Kaplan and Stein (1990) determine implied debt betas for a sample of 12 leveraged recapitalizations of publicly quoted companies. They calculate equity beta factors before and after the transactions and provide the implied debt betas under two different assumptions. In this way, they use three different estimation models. With their first assumption, that operating risks do not change, they find that the equity betas rise surprisingly little, between $37 \%$ and $57 \%$ on average (depending on which method is used to estimate them). This leads to average (median) implied debt beta factors of 0.65 (0.62) for all debt layers of the individual transactions, such as senior and junior debt. Their second assumption is that the operating beta factor is reduced by approximately 25\%. This reduction is linked to the market-adjusted premium paid at the recapitalization, which could represent an anticipation of decreased fixed costs. In this case, the corresponding average (median) implied systematic debt risk is 0.40 (0.35). The method developed by Kaplan and Stein (1990) also offers an alternative way of calculating reduced operating beta factors. If a fixed beta factor for the debt is inserted into their model, a hypothetical reduced operating beta factor can be calculated. They refer to Blume, Keim, and Patel (1989) who provide beta factors for low-grade bonds during different time periods, and use 0.25 as the debt providers' systematic risk for the relevant period. ${ }^{22}$ This results in an average reduction of operating betas by 41\%. Kaplan and Stein (1990) argue that their research should be best considered as yielding ranges of risk, rather than a single estimate. Following their reasoning, the above-cited information on debt betas will be addressed in our sensitivity analysis, where we vary the risk of debt. Also, in a few cases then, the debt betas are larger than the calculated unlevered betas of the target companies. Since equity claims (as residual claims) must be at least as risky as debt claims, we always truncate the risks of debt at the levels of the operating risks. This assumes that, in the less risky transactions, debt and equity investors bear the same (low) risk.

\section{b) Treatment of the Individual Transactions}

Each transaction is analyzed thoroughly in terms of the timing and the character of the underlying cash flows. Our data provides us with the dates and payments at closing and at exit and for add-on investments and premature distributions. Likewise, principle claims linked to the equity and debt cash flows are recorded. For our analysis, common and preferred equity are treated as equivalent. Similarly, all debt is treated as straight debt. Unfortunately, lacking information about the structure of claims, we cannot differentiate rankings or collateral for particular debt layers. We assume that all buyout fund investments are equity investments unless they are explicitly declared as higher ranking properly collateralized debt instruments.

\footnotetext{
22 See Blume, Keim, and Patel (1989), published (1991), Table V.
} 


\section{Appendix (continued)}

This approach considers the fact that investments by a buyout fund can usually be regarded as equity investments in terms of their inherent risk. Even if investments are structured as debt (e.g., shareholder loans), their economic character and risk differs from that of loans. They are usually of a junior rank and are unaccompanied by substantial collateral, thus making all investments resemble equity. All remaining layers other than common or preferred equity provided by third parties are treated as debt.

To build the mimicking portfolio we attribute the same systematic risk as that of the buyout transactions to the mimicking cash flows. The systematic risk for buyout investors consists of the two elements of operating risk and leverage risk. For the operating risks, we use the peer group operating betas as proxies. The leverage risk is determined by the individual transaction structure adopted (and subsequently changed) in the buyout transaction. We know all cash flows from and to investors within the buyout and we know the capital structures for the entry and the exit dates. With this data, we can calculate the initial leverage ratios and the ratios at exit. Between closing and exit we assume that the leverages change linearly. Kaplan (1989a) finds evidence for asset sales and immediate reduction of the degree of leverage following the closing of buyout transactions. Muscarella and Vetsuypens (1990) and Opler (1992) report decreasing investments after closing, while Zahra (1995) cites lower R\&D expenditure. Their results are compatible with the buyout strategy of focusing on core businesses and improving operations and organization during the holding period. From their findings we conclude that the typical buyout deleveraging pattern should be hyperbolic rather than linear but, given the absence of parameters for estimating a hyperbolic function, we retain the linearity assumption.

In order to determine a transaction's risk structure we must differentiate between two general outcomes. First, the investment was successfully exited, providing us with the company valuation, the equity payoff, and hence the degree of leverage at exit. These transactions will be referred to as "non write-offs". Second, the investment was written off ("write-offs"). We assign different assumptions regarding the leverage linearity to both outcomes. The "non write-offs" are entered and exited at certain leverage ratios. During the holding period the leverage ratio either decreases (as in most cases), it grows linearly or stays constant. The "write-offs" are entered into at a given degree of leverage and, by definition, are written off at an infinitely large leverage ratio. This is because the equity value approaches zero while the debt is usually somehow collateralized and therefore retains some value. This leads to problems in terms of the mimicking strategies, because it implies the unrealistic need to leverage investments in public market securities to an infinite exposure. Therefore, we refer to the cause of bankruptcy and assume that the investment was written off because covenants were breached and debt providers claimed their rights. In most cases, this should explain the loss of invested capital. With this reasoning, one can argue that the targeted leverage ratios, defined by loan contracts and covenants, could not be maintained. The debt providers in buyouts usually do not allow their risk to be increased. On the contrary, they insist on debt redemption. For us, this leads us to keep leverage risk constant in the mimicking position over the total holding period of the "write off" buyout transactions. As the leverage ratios could not be successfully lowered, and banks would not allow them to be increased, this appears to be the most rational treatment of them. The approach is further supported by accounting guidelines and best practice rules for 


\section{Appendix (continued)}

buyout funds to immediately write off investments once substantial changes in value such as a breach of covenant takes place. ${ }^{23}$

In the simplest case without add-on investments and premature disbursements, the cash flows can then be duplicated by a single payment at closing and a single payoff at exit. The initial payment takes place at a certain systematic risk level characterized by the operating risk and the additional leverage risk. The systematic risk level at closing is determined by the initial equity beta of the corresponding buyout. The mimicking strategy is structured by investing the same amount of equity in the S\&P 500 Index portfolio and levering it up according to Formula 3 with borrowed funds to achieve an equal systematic risk. If the equity beta of the buyout is lower than one, funds are lent. We assume that the buyouts are settled on the last trading day of the proposed month. The systematic risk of the mimicking strategy is adjusted each year until exit, to secure parity with the buyout. Therefore, the mimicking portfolio is liquidated every year, interest on debt is paid, debt is redeemed and the residual equity is invested in the S\&P 500 Index portfolio being levered to the prevailing systematic risk. Again, if the prevailing beta factor is lower than one, funds are lent. In our base case, we assume that (infinite) lending is possible at the one-year United States treasury-bill rate and that the debt beta is 0 in Formula 3 while the unlevered beta is set equal to 1, the beta factor of the market proxy. However, (infinite) borrowing is associated with higher borrowing cost. The debt beta becomes 0.41 , the beta of high yield debt, and the required debt needed to adjust for the buyout beta increases compared to risk free debt. As a reference for the appropriate credit spreads we use Figure 23 in Altman and Pasternack (2006), who provide credit spreads for high yield securities for the relevant period. The rationale for keeping lending risk free but borrowing risky is to replicate the limited liability of the buyout sponsor. The mimicking investor also must not allow his other assets to serve as collateral for the mimicking transaction. Hence, the remaining collateral is the equity investment in the index portfolio itself, which is bought on the margin. In the sensitivity analyses and robustness checks, we address the debt betas and the corresponding cost to determine our model's sensitivity. The performance of the benchmark portfolio is measured by a total return index calculation on the S\&P 500 corporations provided by DataStream. The risk adjustment procedure is repeated until the exit date. The final payoff of the mimicking strategy and the initial equity investment determine the return of the mimicking investment. If the residual equity of a mimicking investment approaches zero at any time within the holding period, the position is closed and the internal rate of return is calculated up to that point.

\section{c) The Treatment of Add-on Investments and Premature Payoffs}

To consider add-on investments by the funds and premature payoffs to the funds, we need to know the amounts and the investment dates. For the "non write-offs" we simply extrapolate the equity beta at the time of either the add-on investments or the early disbursements. Provided that the payments are not accompanied by changes in debt, they immediately affect the leverage ratios and then follow the same risk pattern as the initial investments. Since we have details of neither the company valuations, nor the prevailing leverage ratios at the time of the

\footnotetext{
${ }^{23}$ See e.g. EVCA (2003).
} 


\section{Appendix (continued)}

add-on investments or disbursements, we cannot correct for the "leverage-jumps". We implement add-on investments and disbursements in our linearity approach. The add-on investments are reflected by the degrees of leverage at exit and, hence, are incorporated into the transactions' final risk levels. This approach might smooth the overall risk patterns. However, if the equity add-on is accompanied by debt in the same proportion as the prevailing capital structure at that time, this approach should hold true. In the mimicking strategy, add-on payments are treated like the initial investments, but take place at a later stage. From the time they are made, they follow the same risk pattern as the initial transaction. Early disbursements lower the capital at risk and therefore we deduct them at the relevant month from the prevailing equity. We determine the internal rate of return of the mimicking strategy until that date and calculate the present value of the disbursement at the transaction closing. That present value is then subtracted from the initial payment giving us two separate cash flows. The remaining equity following disbursement is retained in the mimicking portfolio until the exit, except where it becomes zero or negative. In this case, the position is closed on the disbursement.

For the "write offs" the approach is straightforward. ${ }^{24}$ Add-on investments in the "write off" cases are usually made to prevent the debt providers from claiming bankruptcy. The add-on payments would lower the leverage ratio immediately. However, the debt providers would not necessarily have asked for additional equity if the company's prospects were still good. Debt providers thus demand the payment in order to maintain an acceptable leverage ratio. This leads us to consider that the leverage ratios are unaffected by the add-on investments in "write off" companies. This is supported by the fact that these engagements finally had to be written off, meaning that the debt claims could obviously not be serviced sufficiently and, hence, the leverage ratios could not be lowered.

\section{d) Changes in Ownership}

In some transactions the ownership structure changes within the holding period, either due to non-proportional add-on investments or distributions or by any execution of contingent claims such as conversion rights, or call or put options. If the ownership structure changes, it is noted in the transaction description but not in sufficient detail to permit further investigation. We account for these types of changes in the proportion of the equity stake at exit, thus again assuming that all changes in ownership structure develop linearly over the holding period.

\footnotetext{
${ }^{24}$ Premature disbursements in "write-off" transactions were not observed in our sample.
} 


\section{References}

Altman, Edward I. (1989), "Measuring Corporate Bond Mortality and Performance," in Journal of Finance, Vol. 44, pp. 909-922.

Altman, Edward I. and Pasternack, Brent (2006), "Defaults and Returns in the High Yield Bond Market," Journal of Applied Research in Accounting and Finance, Vol. 1, pp. 3-29.

Arzac, Enrique R. (1996), "Valuation of Highly Leveraged Firms," in Financial Analysts Journal, Vol. 52, July/August, pp. 42-50.

Asquith, Paul, Mullins, David W. Jr., and Wolff, Eric D. (1989), "Original Issue High Yield Bonds: Aging Analyses of Defaults, Exchanges, and Calls," in Journal of Finance, Vol. 44, pp. 923-952.

Asquith, Paul and Wizman, Thierry A. (1990), "Event Risk, Covenants, and Bondholder Returns in Leveraged Buyouts," in Journal of Financial Economics, Vol. 27, pp. 195-213.

Axelson, Ulf, Jenkinson, Tim, Strömberg, Per, and Weisbach, Michael S. (2007), "Leverage and Pricing in Buyouts: An Empirical Analysis," SSRN working paper.

Bae, Sung C. and Simet, Daniel P. (1998), "A Comparative Analysis of Leveraged Recapitalization Versus Leveraged Buyout as a Takeover Defense," in Review of Financial Economics, Vol. 7, pp. 157-172.

Bailey, Martin H., Muth, Richard F., and Nourse, Hugh 0. (1963), “A Regression Method for Real Estate Price Index Construction," in Journal of the American Statistical Association, Vol. 58, pp. 933-942.

Ball, Ray and Brown, Philip (1967), "Some Preliminary Findings on the Association between the Earnings of a Firm, its Industry and the Economy," in Empirical Research in Accounting, Selected Studies, Supplement to Vol. 5, Journal of Accounting Research, pp. 55-77.

Beaver, William and Manegold, James (1975), "The Association between Market Determined and Accounting Determined Risk Measures," in Journal of Financial and Quantitative Analysis, Vol. 10, pp. 231-284.

Berg, Achim and Gottschalg, Oliver (2005), "Understanding Value Creation in Buyouts," in Journal of Restructuring Finance, Vol. 2, pp. 9-37.

Bernado, Antonio E., Chowdhry, Bhagwan, and Goyal, Amit (2004), "Beta and Growth," UCLA Working Paper.

Black, Bernard S. and Gilson, Ronald J. (1998), "Venture Capital and the Structure of Capital Markets: Banks Versus Stock Markets," in Journal of Financial Economics, Vol. 47, pp. 243-277.

Blume, Marshall E., Keim, Donald B., and Patel, Sandeep A. (1989), "The Components of LowerGrade Bond Price Variability," Working Paper (The Wharton School, Philadelphia, PA), published (1991) as: "Returns and Volatility of Low-Grade Bonds 1977-1989," in Journal of Finance, Vol. 46, pp. 49-74. 
Boquist, John A., Racette, George A., and Schlarbaum, Gary G. (1975), "Duration and Risk Assessment for Bonds and Common Stocks,” in Journal of Finance, Vol. 30, pp. 13601365.

Bruton, Garry D., Keels, J. Kay, and Scifres, Elton L. (2002), "Corporate Restructuring and Performance: An Agency Perspective on the Complete Buyout Cycle," in Journal of Business Research, Vol. 55, pp. 709-724.

Bygrave, William, Fast, Norman, Khoylian, Roubina, Vincent, Linda, and Yue, William (1985), "Early Rates of Return of 131 Venture Capital Funds Started 1978-1984," in Journal of Business Venturing, Vol. 4, pp. 93-105.

Bygrave, William and Timmons, Jeffry A. (1992), "Venture Capital at the Crossroads," Boston.

Cochrane, John H. (2005), "The Risk and Return of Venture Capital," in Journal of Financial Economics, Vol. 75, pp. 3-52.

Cornell, Bradford and Green, Kevin (1991), "The Investment Performance of Low-grade Bond Funds," in Journal of Finance, Vol. 46, pp. 29-48.

Cotter, James and Peck, Sarah W. (2001), "The Structure of Debt and Active Equity Investors: The Case of the Buyout Specialist," in Journal of Financial Economics, Vol. 59, pp. 101147.

Cox, John C., Ingersoll, Jonathan E. Jr., and Ross, Stephen A. (1979), "Duration and the Measurement of Basis Risk," in Journal of Business, Vol. 52, pp. 51-61.

Darrat, Ali F. and Mukherjee, Tarun K. (1995), "Inter-Industry Differences and the Impact of Operating and Financial Leverages on Equity Risk," in Review of Financial Economics, Vol. 4, pp. 141-155.

De Angelo, Harry, De Angelo, Linda Elizabeth, and Rice, Edward M. (1984): Going Private: Minority Freezeouts and Stockholder Wealth, in: Journal of Law \&t Economics, Vol. 27, pp. $367-401$.

De Angelo, Harry and De Angelo, Linda Elizabeth (1987), "Management Buyouty of Publicly Trade Corporations," in Financial Analysts Journal, Vol. 43, May/June, pp. 38-49.

Dimson, Elroy (1979), "Risk Measurement when Shares are Subject to Infrequent Trading," in Journal of Financial Economics, Vol. 7, pp. 197-226.

Drees, Burkhard and Eckwert, Bernhard (2000), "Leverage and the Price Volatility of Equity Shares in Equilibrium," in Quarterly Review of Economics and Finance, Vol. 40, pp. 155167.

Elitzur, Ramy, Halpern, Paul, Kieschnick, Robert, and Rotenberg, Wendy (1998), "Managerial Incentives and the Structure of Management Buyouts," in Journal of Economic Behavior \& Organization, Vol. 36, pp. 347-367.

EVCA (2003), EVCA Guidelines, Zaventem.

Fama, Eugene F. and French, Kenneth R. (1997), "Industry Costs of Equity," in Journal of Financial Economics, Vol. 43, pp. 153-193. 
Fisher, Lawrence (1966), “Some New Stock-Market Indexes," in Journal of Business, Vol. 39, Supplement, pp. 191-225.

Fisher, Lawrence and Weil, Roman L. (1971), "Coping with the Risk of Interest-Rate Fluctuations: Returns to Bondholders from Naive and Optimal Strategies," in Journal of Business, Vol. 44, pp. 408-431.

Frecka, Thomas J. and Lee, Cheng F. (1983), "Generalized Financial Ratio Adjustment Processes and their Implications," in Journal of Accounting Research, Vol. 21, pp. 308-316.

Gahlon, James M. and Gentry, James A. (1982), "On the Relationship between Systematic Risk and the Degrees of Operating and Financial Leverage," in Financial Management, Vol. 1, No. 2, pp. 15-21.

Gompers, Paul A. (1998), "Venture Capital Growing Pains: Should the Market Diet?," in Journal of Banking and Finance, Vol. 22, pp. 1089-1104.

Gompers, Paul A. and Lerner, Josh (1997), "Risk and Reward in Private Equity Investments: The Challenge of Performance Assessment," in Journal of Private Equity, Vol. 1, pp. 5-12.

Gompers, Paul A. and Lerner, Josh (1999a), “The Venture Capital Cycle,” Cambridge.

Gompers, Paul A. and Lerner, Josh (1999b), “An Analysis of Compensation in the U.S. Venture Capital Partnership," in Journal of Financial Economics, Vol. 51, pp. 3-44.

Gompers, Paul A. and Lerner, Josh (2000), "Money Chasing Deals? The impact of Fund Inflows on Private Equity Valuations," in Journal of Financial Economics, Vol. 55, pp. 281-325.

Gonedes, Nicholas J. (1969), “A Test of the Equivalent-Risk Class Hypothesis,” in Journal of Financial and Quantitative Analysis, Vol. 4, pp. 159-177.

Gonedes, Nicholas J. (1973), "Evidence on the Information Content of Accounting Numbers: Accounting-Based and Market-Based Estimates of Systematic Risk," in Journal of Financial and Quantitative Analysis, Vol. 8, pp. 407-443.

Graham, John R. (2000), "How Big are the Tax Benefits of Debt?," in Journal of Finance, Vol. 55, pp. 1901-1941.

Groh, Alexander P., Baule, Rainer and Gottschalg, Oliver (2009), "Measuring Idiosyncratic Risks in Leveraged Buyout Transaction," in Quarterly Journal of Finance and Accounting, Vol. 47, No. 4, pp. 5-23.

Hamada, Robert (1972), "The Effect of the Firm's Capital Structure on the Systematic Risk of Common Stocks," in Journal of Finance, Vol. 27, pp. 435-452.

Healy, Paul M. and Palepu, Krishna G. (1990), "Earnings and Risk Changes Surrounding Primary Stock Offers," in Journal of Accounting Research, Vol. 28, pp. 25-48.

Hill, Ned C. and Stone, Bernell K. (1980), “Accounting Betas, Systematic Operating Risk, and Financial Leverage: A Risk-Composition Approach to the Determinants of Systematic Risk," in Journal of Financial and Quantitative Analysis, Vol. 15, pp. 595-637.

Hite, Gailen L. and Vetsuypens, Michael R. (1989), "Management Buyouts of Divisions and Shareholder Wealth,” in Journal of Finance, Vol. 44, pp. 953-970. 
Ho, Thomas S.Y. and Singer, Ronald F. (1984), "The Value of Corporate Debt with a Sinking Fund Provision," in Journal of Business, Vol. 57, pp. 315-336.

Holmstrom, Bengt and Kaplan, Steven N. (2001), "Corporate Governance and Merger Activity in the United States: Making Sense of the 1980s and 1990s," in Journal of Economic Perspectives, Vol. 15, pp. 121-144.

Holthausen, Robert W. and Larcker, David F. (1996), "The Financial Performance of Reverse Leverage Buyouts,” in Journal of Financial Economics, Vol. 42, pp. 293-332.

Huffman, Lucy (1983), “Operating Leverage, Financial Leverage, and Equity Risk," in Journal of Banking and Finance, Vol. 7, pp. 197-212.

Huntsman, Blaine and Hoban, James P. Jr. (1980), "Investment in New Enterprise: Some Empirical Observations on Risk, Return and Market Structure," Financial Management, Vol. 9, pp. 44-51.

Jeng, Leslie A. and Philippe C. Wells (1998), "The Determinants of Venture Capital Funding: Evidence across Countries," SSRN working paper.

Jensen, Michael C. (1986), "Agency Costs of Free Cash Flow, Corporate Finance, and Takeovers," in American Economic Review, Vol. 76, pp. 323-329.

Jensen, Michael C. (1989a), "Eclipse of the Public Corporation," in Harvard Business Review, September-October, pp. 61-74.

Jensen, Michael C. (1989b), "Active Investors, LBOs, and the Privatization of Bankruptcy," in Journal of Applied Corporate Finance, Vol. 2, No. 1, pp. 35-44.

Jensen, Michael C. (1991): Corporate Control and the Politics of Finance, in: Journal of Applied Corporate Finance, Vol. 4, No. 2, pp. 13 - 33.

Jones, Charles M. and Rhodes-Kropf, Matthew (2003): The Price of Diversifiable Risk in Venture Capital and Private Equity, Columbia University Working Paper.

Kaplan, Steven N. (1989a), "The Effects of Management Buyouts on Operating Performance and Value," in Journal of Financial Economics, Vol. 24, pp. 217-254.

Kaplan, Steven N. (1989b), "Management Buyouts: Evidence on Taxes as Source of Value," in Journal of Finance, Vol. 44, pp. 611-632.

Kaplan, Steven N. (1991), "The Staying Power of Leveraged Buyouts," in Journal of Financial Economics, Vol. 29, pp. 287-313.

Kaplan, Steven N. and Ruback, Richard S. (1995), "The Valuation of Cash Flow Forecasts: An Empirical Analysis,” in Journal of Finance, Vol. 50, pp. 1059-1093.

Kaplan, Steven N. and Schoar, Antoinette (2005), "Private Equity Performance: Returns, Persistance and Capital Flows," in Journal of Finance, Vol. 60, pp. 1791-1823.

Kaplan, Steven N., Sensoy, Berk A. and Stromberg, Per (2002), "How well do Venture Capital Databases Reflect actual Investments?, Working Paper, University of Chicago.

Kaplan, Steven N. and Stein, Jeremy C. (1990), "How Risky is the Debt in Highly Leveraged Transactions?," in Journal of Financial Economics, Vol. 27, pp. 215-245. 
Kaplan, Steven N. and Stein, Jeremy C. (1993), "The Evolution of Buyout Pricing and Financial Structure in the 1980s," in Quarterly Journal of Economics, Vol. 108, pp. 313-357.

Lanstein, Ronald and Sharpe, William F. (1978), "Duration and Security Risk," in Journal of Financial and Quantitative Analysis, Vol. 13, pp. 653-668.

Lee, Cheng F. and Wu, Chunchi (1988), "Expectation Formation and Financial Ratio Adjustment Processes," in Accounting Review, Vol. 63, pp. 292-306.

Lehn, Kenneth, Netter, Jeffry, and Poulsen, Annette (1990), "Consolidating Corporate Control: Dual-Class Recapitalizations Versus Leveraged Buyouts," in Journal of Financial Economics, Vol. 27, pp. 557-580.

Lehn, Kenneth and Poulsen, Annette (1989), "Free Cash Flow and Stockholder Gains in Going Private Transactions,” in Journal of Finance, Vol. 44, p. 771-787.

Lerner, Josh (2000), “Venture Capital and Private Equity: A Casebook,” New York.

Lev, Baruch (1974), "On the Association between Operating Leverage and Risk," in Journal of Financial and Quantitative Analysis, Vol. 9, pp. 627-641.

Lichtenberg, Frank and Siegel, Donald (1990), "The Effects of Leveraged Buyouts on Productivity and Related Aspects of Firm Behavior," in Journal of Financial Economics, Vol. 27, pp. 165-194.

Livingston, Miles (1978), "Duration and Risk Assessment for Bonds and Common Stocks: A Note," in Journal of Finance, Vol. 33, pp. 293-295.

Ljungqvist, Alexander and Richardson, Matthew (2003), "The Cash Flow, Return and Risk Characteristics of Private Equity,” NBER Working Paper 9454.

Lockett, Andy, Murray, Gordon, and Wright, Mike (2002), "Do UK Venture Capitalists still have a Bias against Investment in New Technology Firms,” in Research Policy, Vol. 31, pp. 1009-1030.

Lowenstein, Louis (1985), “Management Buyouts," in Columbia Law Review, Vol. 85, pp. 730784.

Mandelker, Gershon N., and Rhee, S. Ghon (1984), "The Impact of the Degrees of Operating and Financial Leverage on Systematic Risk of Common Stock," in Journal of Financial and Quantitative Analysis, Vol. 19, pp. 45-57.

Marais, Laurentius, Schipper, Katherine, and Smith, Abbie (1989), "Wealth Effects of Going Private for Senior Securities,” in Journal of Financial Economics, Vol. 23, pp. 155-191.

Metrick, Andrew (2006), "Venture Capital and the Finance of Innovation," John Wiley \& Sons, Hoboken, NJ.

Metrick, Andrew and Yasuda, Ayako (2008), “The Economics of Private Equity Funds," SSRN Working Paper 996334.

Modigliani, Franco and Miller, Merton (1958), "The Cost of Capital, Corporation Finance, and the Theory of Investment," in American Economic Review, Vol. 48, pp. 261-297. 
Modigliani, Franco and Miller, Merton (1963), “Taxes and the Cost of Capital: A Correction," in American Economic Review, Vol.53, pp. 433-333.

Murray, Gordon C. and Marriott, Richard (1998), "Why has the Investment Performance of Technology-Specialist, European Venture Capital Funds been so poor?," in Research Policy, Vol. 27, pp. 947-976.

Muscarella, Chris and Vetsuypens, Michael R. (1990), "Efficiency and Organizational Structure: A Study of Reverse LBOs,” in Journal of Finance, Vol. 45, pp. 1389-1413.

Myers, Stewart (1974), "Interactions of Corporate Financing and Investment DecisionsImplications for Capital Budgeting," in Journal of Finance, Vol. 39, pp. 1-25.

Myers, Stewart and Ruback, Richard S. (1987), "Discounting Rules for Risky Assets," NBER Working Paper No. 2219.

Nohel, Tom and Tarhan, Vefa (1998), "Share Repurchases and Firm Performance: New Evidence on the Agency Costs of Free Cash Flow," in Journal of Financial Economics, Vol. 49, pp. 187-222.

Opler, Tim C. (1992), "Operating Performance in Leveraged Buyouts: Evidence from 19851989," in Financial Management, Vol. 21, No. 1, pp. 27-34.

Palepu, Krishna G. (1990), “Consequences of Leveraged Buyouts," in Journal of Financial Economics, Vol. 27, pp. 247-262.

Peng, Liang (2001a), “A New Approach of Valuing Illiquid Asset Portfolios," SSRN Working Paper 258599.

Peng, Liang (2001b), “Building a Venture Capital Index,” SSRN Working Paper 281804.

Phalippou, Ludovic (2008), "The Hazards of Using IRR to Measure Performance: The Case of Private Equity," SSRN Working Paper 1111796.

Phalippou, Ludovic and Gottschalg, Oliver (2008), "The Performance of Private Equity Funds," in Review of Financial Studies, forthcoming.

Phalippou, Ludovic (2009), "Beware when Venturing into Private Equity," Journal of Economic Perspectives (forthcoming).

Pogue, Gerald A. and Solnik, Bruno H. (1974), "The Market Model Applied to European Common Stocks: Some Empirical Results," in Journal of Financial and Quantitative Analysis, Vol. 9, pp. 917-944.

Poindexter, John B. (1975), "The Efficiency of Financial Markets: The Venture Capital Case," Dissertation, New York University.

Quigley, John M. and Woodward, Susan E. (2002), "Private Equity before the Crash: Estimation of an Index," University of California Berkeley Working Paper.

Riener, Kenneth D. (1985), “A Pedagogic Note on the Cost of Capital with Personal Taxes and Risky Debt,” in Financial Review, Vol. 20, pp. 229-235.

Rotch, William (1968), "The Pattern of Success in Venture Capital Financing," in Financial Analysts Journal, Vol. 24, September and October, pp. 141-147. 
Ruback, Richard S. (2002), "Capital Cash Flows: A Simple Approach to Valuing Risky Cash Flows," in Financial Management, Vol. 31, No. 2, pp. 85-103.

Rubinstein, Mark E. (1973), “A Mean-Variance Synthesis of Corporate Financial Theory,” in Journal of Finance, Vol. 28, pp. 167-181.

Sahlman, William A. (1990), "The Structure and Governance of Venture-Capital Organizations," in Journal of Financial Economics, Vol. 27, pp. 473-521.

Sahlman, William A. and Stevenson, Howard H. (1985), "Capital Market Myopia," in Journal of Business Venturing, Vol. 1, pp. 7-30.

Scholes, Myron and Williams, Joseph (1977), “Estimating Betas from Nonsynchronous Data," in Journal of Financial Economics, Vol. 5, pp. 309-327.

Schwert, G. Williams (1977), "Stock Exchange Seats as Capital Assets," in Journal of Financial Economics, Vol. 4, pp. 51-78.

Sharpe, William F. and Cooper, Guy M. (1972), "Risk-Return Classes of New York Stock Exchange Common Stocks, 1931-1967," in Financial Analysts Journal, Vol. 28, March/April, pp. 47-54.

Shleifer, Andrei and Vishny, Robert W. (1992), "Liquidation Values and Debt Capacity: A Market Equilibrium Approach,” in Journal of Finance, Vol. 47, pp. 1343-1366.

Smith, Abbie J. (1990), "Corporate Ownership Structure and Performance: The Case of Management Buyouts,” in Journal of Financial Economics, Vol. 27, pp. 143-164.

Woodward, Susan E. and Hall, Robert E. (2003), "Benchmarking the Returns to Venture," NBER Working Paper 10202.

Zahra, Shaker A. (1995), "Corporate Entrepreneurship and Financial Performance: The Case of Management Leveraged Buyouts,” in Journal of Business Venturing, Vol. 10, pp. 225-247. 